\title{
Progressive taxes and firm births
}

\author{
Hans Ulrich Bacher • Marius Brülhart
}

Published online: 30 March 2012

(C) Springer Science+Business Media, LLC 2012

\begin{abstract}
Tax reform proposals in the spirit of the "flat tax" model typically aim to reduce three parameters: the average tax burden, the progressivity of the tax schedule, and the complexity of the tax code. We explore the implications of changes in these parameters for entrepreneurial activity, measured by counts of firm births. The Swiss fiscal system offers sufficient intra-national variation in tax codes to allow us to estimate such effects with considerable precision. We find that high average taxes and complicated tax codes depress firm birth rates, while tax progressivity per se promotes firm births. The latter result supports the existence of an insurance effect from progressive corporate income taxes for risk-averse entrepreneurs. However, implied elasticities with respect to the level and complexity of corporate taxes are an order of magnitude larger than elasticities with respect to the progressivity of tax schedules.
\end{abstract}

JEL Classification $\mathrm{H} 32 \cdot \mathrm{H} 2 \cdot \mathrm{H} 7 \cdot \mathrm{R} 3$

Keywords Progressive taxation · Entrepreneurship · Risk taking · Firm location · Count models

H.U. Bacher

Credit Suisse AG, 8070 Zurich, Switzerland

e-mail: hans.u.bacher@credit-suisse.com

M. Brülhart $(\bowtie)$

Department of Economics, Faculty of Business and Economics, University of Lausanne,

1015 Lausanne, Switzerland

e-mail: Marius.Brulhart@unil.ch

M. Brülhart

Centre for Economic Policy Research, London, UK 


\section{Introduction}

Despite a recent recession-induced shift toward more progressive taxation, the flattax model retains widespread appeal. By March 2012, 26 countries were operating flat-rate income tax systems, as were seven US states. ${ }^{1}$ Many other countries and regions have considered reforms that would flatten their tax schedules. The most frequently invoked argument in favor of flat taxes is that they simplify both compliance and enforcement, but moving toward flat-rate taxation has a host of other economic implications, in terms of both efficiency and equity. ${ }^{2}$ In this paper, we focus on one efficiency-related dimension of a particular type of flat tax: the impact of flat-rate corporate income taxes on the generation of new firms. ${ }^{3}$

The specific choice between flat and progressive corporate tax rates is a topic of ongoing debate in a number of industrialized countries. The United States, for example, raises a progressive federal corporate income tax, as do Japan and the United Kingdom. Conversely, Canada, France, Germany, Italy and Spain apply essentially flat-rate corporate taxes (with some exceptions for small businesses). The two approaches sometimes coexist at sub-national level. In the United States, 31 states levy flat-rate corporate income taxes, 17 states levy progressive corporate income taxes and three states do not tax corporate income.

Births of new firms, in turn, are of interest for at least two reasons. First, we consider them a proxy for entrepreneurship, which, following Schumpeter, has come to be regarded as a key driver of economic growth. ${ }^{4}$ Second, the number of firms choosing to start operations in a particular jurisdiction can be taken as a measure of that jurisdiction's locational attractiveness.

Our empirical work is based on data for Switzerland, which offers a well suited setting for an analysis of this issue. While the Swiss federal government levies a flatrate corporate income tax, a wide variety of (flat and progressive) tax schedules are applied at the sub-federal level, by Switzerland's 26 fiscally autonomous cantons. Furthermore, below the cantonal level, some 2,700 municipalities levy taxes at often very different average rates and with some further variations in progressivity.

We exploit the variation of tax schedules within Switzerland for an analysis of the impact of corporate tax progressivity on the creation of new firms. Our analysis is organized around three dimensions of corporate income taxes: the implications

\footnotetext{
${ }^{1}$ See en.wikipedia.org/wiki/Flat_tax.

${ }^{2}$ See, e.g., Keen et al. (2008) for a general appraisal of recent flat-tax reforms.

${ }^{3}$ By considering corporate taxes in isolation, we take a narrower view than the most radical flat-tax model, in which a single tax rate is applied across all tax bases and corporate income may be taxed only when paid out as dividends (see, e.g., Hall and Rabushka 2007).

${ }^{4}$ This intuitive assertion finds theoretical support in endogenous growth models, where entrepreneurs are primarily cast in the role of conduits between scientific research and market-oriented production (see, e.g., Michelacci 2003). We can also invoke some relevant empirical evidence. Reynolds et al. (1995) and Audretsch and Fritsch (2002) have found that regions with higher firm formation rates enjoy higher growth, in the United States and Germany, respectively. These results were broadly confirmed by a number of country-level studies in the January 2008 special issue of Small Business Economics (see Fritsch 2008). Employing indirect measures of entrepreneurship, Glaeser et al. (1992) have found industry-level employment growth to be higher in US with below-average firm sizes; and Murphy et al. (1991) have reported positive growth effects of the share of engineering graduates in a large cross section of countries.
} 
of higher or lower average tax burdens (the "level effect"), the implications of progressivity (the "insurance effect"), and the implications of tax complexity. To the best of our knowledge, ours is the first study to evaluate these three effects jointly. The smallness and regulatory homogeneity of Switzerland coupled with considerable intra-national variance in tax regimes limit the potential for estimation bias due to unobserved locational determinants of firm births.

The remainder of this paper is organized as follows. In the next section we review the relevant literatures on firm births, firm location, taxation and risk taking. In Sect. 3, we present a simple model of risk taking and progressive taxation to formalize the intuition of the insurance effect. In Sect. 4 we present our empirical model and our data set for Switzerland. Estimation results are reported and discussed in Sect. 5. Section 6 concludes.

\section{Literature background: taxes and firm births}

\subsection{The tax level effect}

The three dimensions of corporate tax policy we focus on have previously been subject to very different degrees of scientific scrutiny. While relatively little attention has been paid to the effect of corporate tax progressivity, and even less evidence exists on the implications of tax complexity, there exists an extensive theoretical and empirical literature on the effect of changes in the level of (average and marginal) corporate tax rates. The available evidence strongly supports the existence of a moderating impact of the level of corporate taxes on firm births at both the national and the local level. ${ }^{5}$

In a related strand of literature, economists have explored the impact of corporate tax levels on "income shifting" between the personal and the corporate tax base. Most tax systems leave considerable room for manoeuvre on this choice, mainly via different organizational forms and via flexible accounting rules governing the heading under which the remuneration of owner-workers is declared. Several available studies show that, not surprisingly, the share of income that is declared as corporate is higher the lower is the level of corporate relative to personal income taxes (see, e.g., Gordon and Slemrod 2000; Goolsbee 2004; Cullen and Gordon 2007; and de Mooij and Nicodème 2008). Some of the observed income shifting into the corporate tax base is due to the incorporation of previously non-corporate organizations or due to the division of larger corporations into smaller firms. In that sense, income shifting also contributes to the creation of new firms.

\subsection{The tax progressivity effect (insurance effect)}

If tax payers' decisions are made under uncertainty, the progressivity of tax schedules will have implications that differ from those of the level of (average effective) taxes.

\footnotetext{
${ }^{5}$ For international evidence, see e.g. de Mooij and Ederveen (2003), Hines (2007), and Da Rin et al. (2011); and for recent intra-national evidence see Feld and Kirchgässner (2003), Guimaraes et al. (2004), Rathelot and Sillard (2008), Duranton et al. (2011), and Brülhart et al. (2012).
} 
Thus, under uncertainty, the variance of the tax bill matters in addition to the expected level of the tax bill.

Domar and Musgrave (1944) have famously shown that taxation can encourage risk taking. ${ }^{6}$ Whilst assuming a flat-tax schedule, they also took account of lossoffset provisions that imply a negative tax in case of losses. A higher tax rate then reduces both the expected level and the expected variance of post-tax income, which, depending on investor preferences, may make risky ventures relatively more attractive by reducing risk through an implied insurance effect of taxation.

The Domar-Musgrave model, by featuring a flat tax over positive income, is not well suited to a formal distinction between the implications of changes in the level of the expected tax bill and changes in progressivity per se. An intuitive conjecture from the Domar-Musgrave result is that increased progressivity, provided it does not affect the expected tax bill, should be favorable to entrepreneurial risk taking. ${ }^{7}$ This intuition is supported to some extent by formal analysis. Ahsan (1974) considered investment in a risky asset under a flat-rate tax with and without a tax-exempt threshold, the former corresponding to a progressive schedule. Conditional on constant expected tax revenue, he found that risk taking is greater under the progressive tax than under the proportional tax, given standard assumptions on investors' aversion to risk. In a similar model, Cowell (1975) found that progressivity favors investment in the risky asset if the utility function is assumed to be quadratic, but may deter risk taking under different preferences. ${ }^{8}$ Gordon (1985), allowing for a general form of risk aversion and corporate tax progressivity in a general-equilibrium setting, found that raising the marginal tax rate, other things equal, promotes investment while raising the average tax rate, other things equal, discourages investment. Waterson (1985) considered the implications of a quadratic tax function, again assuming a constant expected tax bill. He concluded that, while the effect of progressivity on risk taking is positive for certain parameter configurations, its sign cannot be established in general. ${ }^{9}$

Empirically, the impact of personal income tax progressivity on entry into selfemployment has been explored by Gentry and Hubbard (2000, 2005). They report negative impacts of personal income progressivity on entrepreneurship. The main explanation for these findings is that progressive taxation acts as a "success tax" on profitable ventures: since entrepreneurs on average have higher incomes than employees,

\footnotetext{
${ }^{6} \mathrm{~A}$ corresponding analysis concerning personal income taxes has been provided by Varian (1980).

${ }^{7}$ Cullen and Gordon (2006b) have put it as follows: "For any given tax treatment of losses, a progressive tax schedule on profits, holding expected taxes constant, should encourage risk taking. With progressive rather than proportional taxes, the owners get to keep a smaller fraction of large profits but a larger fraction of small profits. If expected tax payments are held fixed, this is a trade-off that any risk-averse individual gains from making."

${ }^{8}$ Cowell (1975) used the term "compensation" for what we refer to as the "constant expected tax bill" condition.

${ }^{9}$ If entrepreneurial ventures are externally financed and entrepreneurs are subject to moral hazard (i.e. they have an incentive to shirk if their stake in the success of the venture is low), then the risk-reducing element implicit in progressive taxation may impede entrepreneurship (see e.g. Keuschnigg and Nielsen 2004; and Hagen and Sannarnes 2007). To the extent that the incidence of progressive taxation is felt by financiers rather than by entrepreneurs, however, the findings of the earlier literature on taxation and risk taking still apply.
} 
progressive income taxation discourages entrepreneurial risk taking. Crucially, however, this effect confounds the impact of tax progressivity with that of the expected tax bill. ${ }^{10}$

Cullen and Gordon (2007) have estimated a model of entrepreneurial risk, controlling for both level and progressivity effects of corporate tax schedules using US data. Entrepreneurial risk taking is defined empirically as the fraction of single tax filers who report active non-corporate losses in excess of 10 percent of reported wage income. While their estimated regression coefficients represent the impact of composite terms capturing "income shifting" and "combined risk" effects inherent in the tax code, and therefore elude simple interpretation, their derived simulation results reported in Cullen and Gordon (2006a) show that a revenue-neutral shift to a flat tax à la Hall and Rabushka (2007) would reduce entrepreneurial risk taking by more than half. Their results are thus consistent with economically significant insurance effects. The main difference between our approach and that of Cullen and Gordon (2006a, 2007 ) is that we explore the impact of taxation on the birth rates of incorporated firms across different locations, whereas they focus on entrepreneurial individuals reporting high losses across quantiles of predicted potential earnings. Our empirical setting offers inter-jurisdictional variation in the entire tax schedule. It thereby allows a simple quantification of the various relevant dimensions of tax policy.

\subsection{The tax complexity effect}

A third way in which a change to a flat corporate income tax could potentially influence entrepreneurship (in sectors other than accounting and legal services) is by simplifying compliance via a reduction in complexity. Complexity has two components: the number of tax brackets and the definition of the tax base.

First, calculating tax liabilities is simpler with a single statutory tax rate than with a progressive tax schedule featuring multiple tax brackets. It seems reasonable, however, to question the practical importance of the complexity implied by progressive schedules alone. ${ }^{11}$

The most compelling case for the view that complexity raises compliance costs can be made if one moves beyond the narrow implications of progressivity alone and considers the statutory definitions of the tax base. Administrative complications are most evident where numerous different types of tax base are distinguished and where the definitions of tax bases are subject to exceptions, deductions, tax credits and the like. Such complexity is not a necessary correlate of progressivity, but flat-tax proposals usually involve a reduction both in progressivity and in the complexity of the determination of the tax base.

\footnotetext{
${ }^{10}$ Gentry and Hubbard $(2000,2005)$ have regressed the probability that an individual switches from employment to self-employment on a set of variables including (a) the projected tax rate in case of unchanged employment status and (b) a measure of tax progressivity computed as the difference in tax rates between a "successful" scenario, where taxable income increases by $x$ percent, and an "unsuccessful" scenario, where taxable income decreases by $y$ percent. They did not, however, control for the expected (i.e. probability weighted) tax rate in case of a switch to self-employment.

${ }^{11}$ To cite Slemrod and Bakija (2004, p. 166), "a graduate tax-rate structure does not by itself directly contribute any significant complexity to the taxpaying process. Once taxable income is computed, looking up tax liability in the tax tables is a trivial operation (...)."
} 
Edmiston et al. (2004) found that the number of special corporate tax rates had a significantly negative impact on flows of foreign direct investment into European and Asian transition countries in the 1990s. However, and somewhat paradoxically, they report positive coefficients on an alternative complexity variable defined as the number of lines in the respective tax codes (similar to the measure that we will apply). ${ }^{12}$ We are not aware of any prior empirical work relating firm births to the two components of tax complexity.

\section{A simple model of tax progressivity and entrepreneurship}

In this section, we present a highly stylized model to formalize the effect of progressivity on entrepreneurial risk taking, given a certain expected tax bill. As noted above, this effect has been analyzed before (Ahsan 1974; Cowell 1975; Waterson 1985). We propose a simple framework primarily for its heuristic value. ${ }^{13}$

Suppose a risk-averse entrepreneur has to choose where to locate her firm. She will make a high or low profit at the end of the year with a certain probability. The only salient difference between two potential locations arises from their corporate income tax schedules: one location features a flat tax while the other location has a progressive schedule. We ask which location the entrepreneur is better off choosing, provided that the expected corporate tax payments are the same in both locations. This constant expected tax bill condition is crucial to our analysis. Keeping the expected after-tax profit constant, progressive taxation reduces the variance of profits by more than linear taxation. As a consequence, tax progressivity serves as an insurance device: in bad times, an entrepreneur has to pay less than under a flat tax, whereas in good times the tax bill is higher. This, in a nutshell, is how progressivity can favor entrepreneurial risk taking.

To formalize the intuition, consider a risk-averse entrepreneur with a standard Bernoulli utility function over income $w, U(w)$, with $U_{w}(w)>0$ and $U_{w w}(w)<0$. The entrepreneur faces a simple lottery $L=\left(p_{L}, p_{H}\right)$ over two possible profit outcomes $\left\{\pi_{L}, \pi_{H}\right\}$, with $\pi_{H}>\pi_{L}$ and $\pi_{L} \neq 0 .{ }^{14}$

Profits are subject to either a flat or progressive tax schedule, defined as:

- flat tax rate: $t$

- progressive tax rate: $t_{L}^{\text {prog }}=t+k_{L}$ if $\pi=\pi_{L}$ and $t_{H}^{\text {prog }}=t+k_{H}$ if $\pi=\pi_{H}$ with $k_{L}<0<k_{H}$, where $k_{L}, k_{H}$ are constants.

\footnotetext{
${ }^{12}$ Edmiston et al. (2004) explain the apparent positive effect of the length of tax codes by pointing out that more lines could imply greater legal precision-an aspect which might indeed be relevant in transition countries.

${ }^{13}$ The main simplification of our approach compared to existing theory is that we constrain the range of choices to two options. This simplification allows us to posit a general (Bernoulli) utility function, which, unlike those adopted in prior studies, need not exhibit increasing absolute risk aversion (see also Feldstein 1969). Cullen and Gordon (2006a) propose a similar model, taking utility as the log of income.

${ }^{14}$ This framework also applies to cases where $\pi_{L}<0$. In such cases, the corporate tax rate turns negative, implying a subsidy (e.g. through loss-offset or carry-forward provisions). Since taxation in our model does not include a lump-sum tax part (payable independently of the realization of profits), we exclude $\pi_{L}=0$. In our model, if $\pi_{L}=0$, only $\pi_{H}$ would be taxed (at the same rate as the flat tax rate).
} 
In addition, we impose the following three conditions:

Condition 1 (Constant expected tax bill condition) The expected tax bill is constant:

$$
\left[t+k_{L}\right] p_{L} \pi_{L}+\left[t+k_{H}\right] p_{H} \pi_{H}=t p_{L} \pi_{L}+t p_{H} \pi_{H} .
$$

Hence, expected after-tax income is assumed to be the same under the two tax schedules.

Condition 2 (Spread condition)

Risk is a function of the spread (the difference) of the two outcomes, $\pi_{L}$ and $\pi_{H}$, whereas the probabilities and expected pre-tax profits are held constant.

This defines $\pi_{L}$ :

$$
\pi_{L}=\frac{\bar{\Pi}-\bar{p}_{H} \pi_{H}}{\bar{p}_{L}},
$$

where $\bar{\Pi}=p_{L} \pi_{L}+p_{H} \pi_{H} \geq 0$ is expected pre-tax profit, and upper bars design constants.

This condition implies that an increase in the variance of post-tax income $w$ (and thus in risk) follows only from an increase in the spread of the two pre-tax profit levels. For notational ease, we suppress the upper bars henceforth. ${ }^{15}$

Conditions 1 and 2 allow us to express $k_{L}$ as a function of $\pi_{L}, \pi_{H}$ and $k_{H}$ :

$$
k_{L}=-\frac{p_{H} \pi_{H}}{\Pi-p_{H} \pi_{H}} k_{H} \text {. }
$$

Condition 3 (No-reversal condition) Post-tax income in the low-profit outcome cannot be higher than post-tax income in the high-profit outcome:

$$
\left[1-t-k_{L}\right] \pi_{L} \leq\left[1-t-k_{H}\right] \pi_{H} .
$$

Hence, tax rates are not allowed to be so progressive as to reverse the ordering of the post-tax outcomes relative to the pre-tax outcomes.

Expected utility with a flat-tax schedule then takes the following form:

$$
\begin{aligned}
E U\left(w^{\text {flat }}\right) & =p_{L} U\left([1-t] \pi_{L}\right)+p_{H} U\left([1-t] \pi_{H}\right) \\
& =p_{L} U\left([1-t] \frac{\Pi-p_{H} \pi_{H}}{p_{L}}\right)+p_{H} U\left([1-t] \pi_{H}\right),
\end{aligned}
$$

while expected utility with a progressive tax schedule becomes

$$
\begin{aligned}
E U\left(w^{\text {prog }}\right)= & p_{L} U\left(\left[1-t-k_{L}\right] \pi_{L}\right)+p_{H} U\left(\left[1-t-k_{H}\right] \pi_{H}\right) \\
= & p_{L} U\left(\left[1-t+\frac{p_{H} \pi_{H}}{\Pi-p_{H} \pi_{H}} k_{H}\right] \frac{\Pi-p_{H} \pi_{H}}{p_{L}}\right) \\
& +p_{H} U\left(\left[1-t-k_{H}\right] \pi_{H}\right) .
\end{aligned}
$$

\footnotetext{
${ }^{15}$ In what follows, brackets are used for mathematical operations, whereas parentheses are used for functions.
} 
We can now explore whether a change from a flat to a progressive tax schedule benefits a risk-averse entrepreneur.

Proposition 1 Expected utility is higher with a progressive tax schedule than with a flat-rate tax:

$$
\left.\frac{\partial\left[E U\left(w^{\text {prog }}\right)-E U\left(w^{\text {flat }}\right)\right]}{\partial k_{H}}\right|_{k_{H}=0}>0 .
$$

Proof Taking the derivative with respect to $k_{H}$ around $k_{H}=0$ results in

$$
\left.\frac{\partial \Delta E U(w)}{\partial k_{H}}\right|_{k_{H}=0}=-p_{H} \pi_{H}\left[U_{w}\left(w_{H}^{\text {prog }}\right)-U_{w}\left(w_{L}^{\text {prog }}\right)\right]>0,
$$

where $\Delta E U(w)=E U\left(w^{\text {prog }}\right)-E U\left(w^{f l a t}\right)$, and $U_{w}\left(w_{\ell}^{\text {prog }}\right)=U_{w}\left(\left[1-t-k_{\ell}\right] \pi_{\ell}\right)$, $\ell=\{L, H\}$.

This is the insurance effect: progressive taxation reduces the variance (and thus risk) by more than a flat rate. Therefore, the expected utility of after-tax income is higher under progressive taxation and a risk-averse entrepreneur prefers progressive to flat taxation.

The logic of this simple model can be applied both to the location decision (choice between a location with a progressive tax and a location with a flat tax) and the entry-into-self-employment decision. Figure 1 illustrates this. Take the location decision, and suppose the two possible realizations $\pi_{L}$ and $\pi_{H}$ are equally probable. The entrepreneur can choose between two locations. The first one has a flat tax rate, and the corresponding after-tax realizations of $\pi_{L}$ and $\pi_{H}$ are $w_{L}^{\text {flat }}$ and $w_{H}^{\text {flat }}$, respectively. At the second location, after-tax realizations of $\pi$ are $w_{L}^{\text {prog }}$ and $w_{H}^{\text {prog }}$. By the definition of progressive taxation and given the no-reversal condition, $w_{L}^{\text {flat }}$ $<w_{L}^{\text {prog }}<w_{H}^{\text {prog }}<w_{H}^{f l a t}$. From the concavity of the utility function it follows that expected utility with a progressive tax, $E U\left(w^{\text {prog }}\right)$, is higher than expected utility with a flat tax, $E U\left(w^{f l a t}\right)$ : the entrepreneur prefers the location with the progressive tax.

The same analysis can be applied to the entry decision. Again, suppose equally probable realizations $\pi_{L}$ and $\pi_{H}$. Suppose that under a progressive tax the potential entrepreneur is just indifferent between entering self-employment and being employed, in which case she receives a fixed wage corresponding to the certainty equivalent of $E U\left(w^{\text {prog }}\right){ }^{16}$ Imagine a switch to a flat tax. As a consequence, and easily seen in Fig. 1, the expected utility from being self-employed, $E U\left(w^{f l a t}\right)$ decreases and so does the corresponding certainty equivalent (not drawn). Now, the potential entrepreneur unequivocally prefers remaining in risk-free employment.

It is intuitive, given the logic of the insurance effect of progressive taxation, that this effect becomes more pronounced for riskier ventures: the greater is the dispersion of uncertain outcomes, the more a potential entrepreneur stands to gain from progressive taxation. This can be expressed formally as follows.

\footnotetext{
${ }^{16}$ The certainty equivalent of $E U\left(w^{\text {prog }}\right)$ is not represented in Fig. 1. From Jensen's inequality it follows that this point is located to the left of $E$ ( $\left.w^{f l a t, p r o g}\right)$.
} 


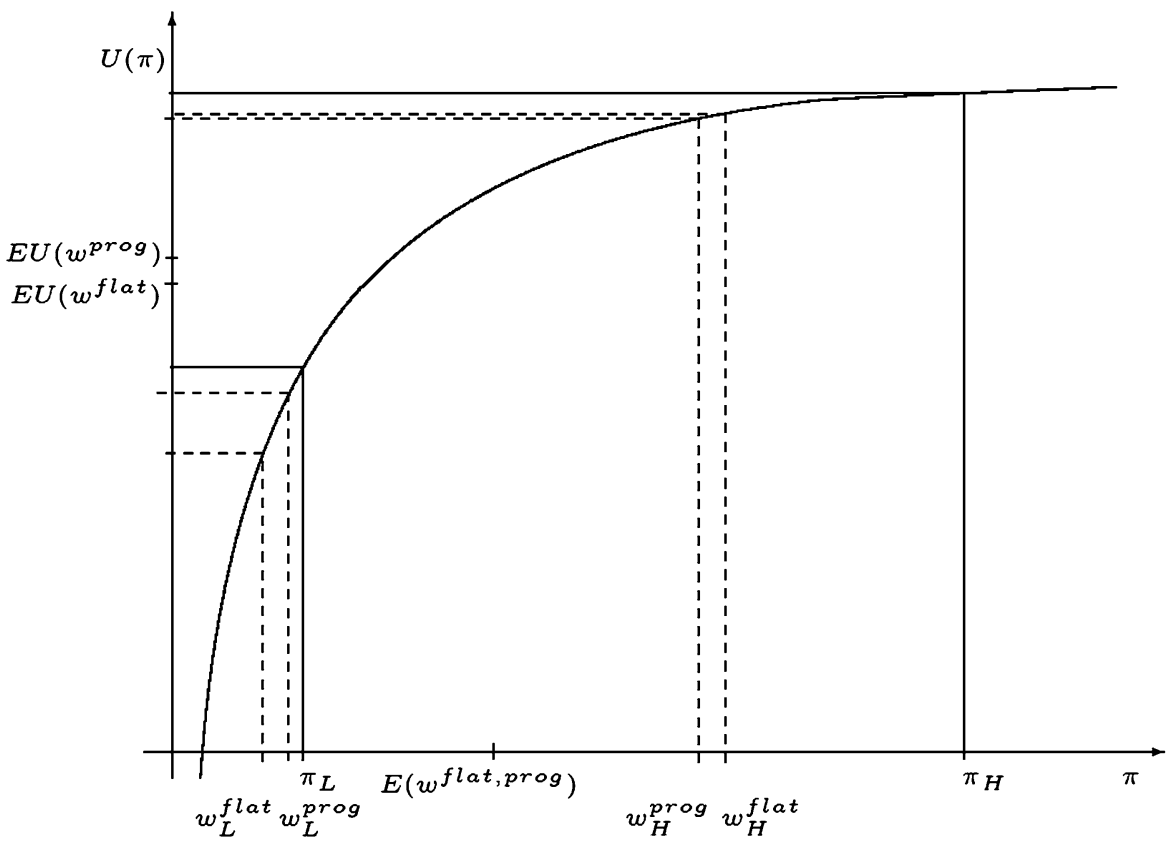

Fig. 1 Expected utility with flat and progressive taxation

Proposition 2 The greater is the spread between $\pi_{L}$ and $\pi_{H}$, the more an increase in progressivity is preferred:

$$
\frac{\partial^{2} \Delta E U(w)}{\partial k_{H} \partial \pi_{H}}>0 .
$$

Proof See Appendix A.

\section{Empirical model and data}

\subsection{A count model of firm births}

Our empirical project is straightforward: we seek to estimate the impact of the level, the progressivity and the complexity of corporate taxes on entrepreneurial activity.

We represent entrepreneurial activity by the entry of new firms. New firms can be created in a jurisdiction through two basic processes. In the "latent-startup" process, immobile local residents are potential entrepreneurs who continuously compute the discounted expected utility from creating a firm and become active once that value exceeds the utility associated with their outside option. In the "footloose-startup" process, entrepreneurs are mobile and scan potential locations for the best certainty equivalent profit opportunity, conditional on having decided to set up a firm.

Despite the fundamental differences between the two processes, they have both been shown formally to be compatible with a Poisson count model of firm births. The 
latent-startup process has been modeled by Becker and Henderson (2000) and shown to lead directly to a Poisson model, subject to standard regularity conditions. Starting with Carlton (1983), the footloose-startup process has traditionally been modeled through a conditional logit representation, which can be formally derived from firmlevel profit functions. Guimaraes et al. (2003) have demonstrated that Poisson estimation with group fixed effects returns identical coefficients to those obtained with conditional logit estimation. ${ }^{17}$

We can therefore directly write an expression for $E\left(n_{i j t}\right)$, the expected number of new firms (or of jobs in new firms) created in jurisdiction $i$, sector $j$ and year $t$ :

$$
\begin{aligned}
E\left(n_{i j t}\right)= & \lambda_{i j t} \\
= & \exp \left(\alpha_{1} \text { corptaxlevel }_{i j t}+\alpha_{2} \text { corptaxprogressivity }_{i t}\right. \\
& +\alpha_{3} \text { risk }_{j} * \text { corptaxprogressivity }_{i t}+\alpha_{4} \text { corptaxcomplexity }_{i t} \\
& \left.+\boldsymbol{\beta}^{\prime} \text { taxcontrols }_{i j t}+\boldsymbol{\gamma}^{\prime} \text { othercontrols }_{i j t}+\boldsymbol{\theta}^{\prime} \mathbf{d}_{j}+\zeta^{\prime} \mathbf{d}_{t}\right),
\end{aligned}
$$

where $n_{i j t}$ follows a Poisson distribution, corptaxlevel is a measure of the expected average corporate income tax rate, corptaxprogressivity is a measure of the overall progressivity of the corporate income tax schedule, corptaxcomplexity is a measure of the complexity of the corporate tax code, risk is a measure of the inherent riskiness of entrepreneurial ventures in sector $j$, taxcontrols is a vector of variables to represent tax burdens other than those on corporate profits, othercontrols is a vector of non-tax factors influencing the likelihood of firm births, $\mathbf{d}_{j}$ is a set of sector dummies, and $\mathbf{d}_{t}$ is a set of year dummies.

Our four hypotheses are:

1. $\alpha_{1}<0$ (the effect on firm births of the expected corporate income tax level is negative),

2. $\alpha_{2}>0$ (following Proposition 1, the effect on firm births of tax progressivity is positive),

3. $\alpha_{3}>0$ (following Proposition 2 , the positive effect of tax progressivity is stronger in inherently riskier sectors), and

4. $\alpha_{4}<0$ (the effect on firm births of tax schedule complexity is negative).

\subsection{Identification and inference}

When seeking to identify the coefficients of our empirical model (3), we face the potential problem that, in general, corporate tax rules may be both cause and consequence of firms' location choices. Resident firms influence local tax provisions through the local tax base or through the political process of local tax setting. Our strategy for avoiding potential simultaneity bias is to study location choices of new firms in narrow sectors. While it is easy to conceive how existing firms in a jurisdiction together may influence local taxation, we consider it highly unlikely that entrants

\footnotetext{
${ }^{17}$ The interpretation of the estimated coefficients, can be quite different; with the conditional logit implying a "zero-sum" reallocation of a fixed number of firms and the Poisson implying a pure "positive-sum" taxinduced generation of new firms (Schmidheiny and Brülhart 2011).
} 
in a particular sector, location and period exert significant and systematic influence on pre-existing local tax rates. In our empirical setting, local jurisdictions are legally bound to apply identical statutory taxes across all sectors. ${ }^{18}$ We therefore consider tax rates to be exogenous not only from the viewpoint of an individual firm but also from that of a cohort of new firms in a particular sector, location and period. ${ }^{19}$

Another challenge to identification concerns the variable corptaxlevel, which stands for the expected corporate tax rate. With progressive tax schedules, the expected tax rate depends on expected profitability, which also affects the rate of firm births. Hence, our estimates of $\alpha_{1}$ might be biased. Furthermore, to underestimate expected profitability would tend to bias estimates of $\alpha_{2}$ and $\alpha_{3}$ downward, and to overestimate it would tend to bias them upward, because progressivity would then correlate with the mismeasured expected tax rate. Specifically, when expected profitability is underestimated, this will tend to induce a positive correlation between the unobserved component of the true expected tax rate and the progressivity measure, thus biasing downward the estimated $\alpha_{2}$. It is therefore important to take account of any systematic differences in expected profitability. We compute corptaxlevel separately for each sector-location pair, based on observed sector-average profitability rates. To the extent that firms' expected profitability is sector specific conditional on the included regressors, our coefficient estimates will be unbiased.

Finally, we need to think carefully about potential specification and omittedvariable bias. In the absence of a natural experiment and of sufficient intertemporal variation, we have to rely essentially on cross-section identification. Our approach is to control for all conceivably relevant determinants of firm births in addition to the tax variables and to test the robustness of the estimated tax effects across a range of specifications. The smallness and institutional homogeneity of Switzerland plays to our advantage in this respect, as it facilitates our task of generating an exhaustive set of controls.

Some features of our research design affect inference. First, the Poisson model implies that the expected count, $\lambda_{i j t}$, is equal to the variance of $n_{i j t}$. This is a strong assumption in our applications, as the variance mostly exceeds the expected count (overdispersion), and as we observe a large number of zero observations on the dependent variable. Second, our model includes several explanatory variables that are purely municipality-year specific (such as the progressivity of the corporate tax schedule), while the dependent variable is municipality-sector-year specific. Such aggregate variables bias the estimated standard errors downward if not correctly adjusted for (Moulton 1986). Third, we observe firm startups over five years. We cannot

\footnotetext{
${ }^{18}$ Corporate taxation in Switzerland is based on legally binding statutory rates that depend solely on firms' profitability and capital base. The definitions of these tax bases have been harmonized countrywide by a federal law that has been in force since 1993 and that foresees no firm-specific or sector-specific regimes except for some clauses to avoid double taxation of holding companies. Some (mainly industrial) firms can be offered tax rebates for a maximum of ten years after setting up a new operation. Available evidence suggests that they affect less than 4 percent of new firms (Brülhart et al. 2012).

${ }^{19}$ In principle, there could be unobserved exogenous shocks that have direct causal effects on both the progressivity of local tax schedules and on sector-level firm births, thus potentially biasing our estimated tax effects. While such a configuration does not strike us as likely, we cannot rule it out categorically, as our data do not allow us to instrument the tax variables. We seek to mitigate this potential problem by including a large set of controls.
} 
exploit this panel structure by including location-sector fixed effects, as the changes over time in our main explanatory are too small for the identification of any statistically significant effects. However, the possible presence of location-sector random effects needs to be taken into account when estimating standard errors. All three issues are addressed by clustering standard errors in the two dimensions: by municipalityyear and by municipality-sector. We therefore apply multi-way clustering as proposed by Cameron et al. (2011). Clustering by municipality-year takes care of the second issue discussed above, clustering by municipality-sector addresses the third issue, and either of the clusters automatically accommodates the first issue. ${ }^{20}$

\subsection{Data}

\subsubsection{The Swiss corporate tax system}

Several features of its political structure and tax system make Switzerland particularly well suited to serve as a laboratory for research on the effects of fiscal policy. Specifically, the Swiss system features three propitious characteristics.

1. Local tax autonomy

Swiss taxes on corporate as well as on personal income are levied at three hierarchically nested jurisdictional levels: by the federal government, by the 26 cantons and by some 2,700 municipalities. The federal government taxes profits at a flat rate of $8.5 \%$ and does not tax corporate capital. The cantons enjoy complete autonomy in the setting of their tax schedules. They all levy taxes on profits and corporate capital as well as on personal income and wealth. In 21 of the 26 cantons, municipalities apply a single multiplier to the applicable cantonal tax schedules. ${ }^{21}$ In the remaining cantons, the same multiplier applies to all municipalities within the canton, implying no municipal autonomy (see Table 1, last column).

2. Heterogenous tax schedules

The autonomy of local tax setters yields large intra-national variance in taxation. The geography of corporate tax burdens is illustrated in Fig. 2, which shows consolidated cantonal and municipal average corporate income tax rates on a representative firm for the 26 cantonal capitals. The highest tax rate (Geneva, $23.5 \%$ ) exceeds the lowest tax rate (Zug, 6.4\%) by a factor of nearly four. As can be gleaned from Figs. 3 and 4 for 2001 and 2005, respectively, the progressivity of these tax schedules exhibits similar intra-national heterogeneity. Eleven cantons, among them the cantons of Zurich (since 2005) and Geneva, apply a flat tax rate on profits. The remaining fifteen cantons apply progressive schedules with two or

\footnotetext{
${ }^{20}$ Clustering being a variant of the Eicker-White "sandwich" variance estimator, it provides consistent standard error estimates even in the presence of overdispersion (see e.g. Cameron and Trivedi 1998, p. $65 f$.). We also estimated our standard errors using one-way clustering by municipality and three-way clustering by municipality, sector and year, but did not find our inference results to be significantly affected.

${ }^{21}$ In 8 of those 21 cantons, municipalities decide on a single multiplier that applies to both personal and corporate taxes. In the remaining 13 cantons, at least some municipalities apply separate multipliers to the two tax bases. See also Brülhart and Jametti (2006).
} 


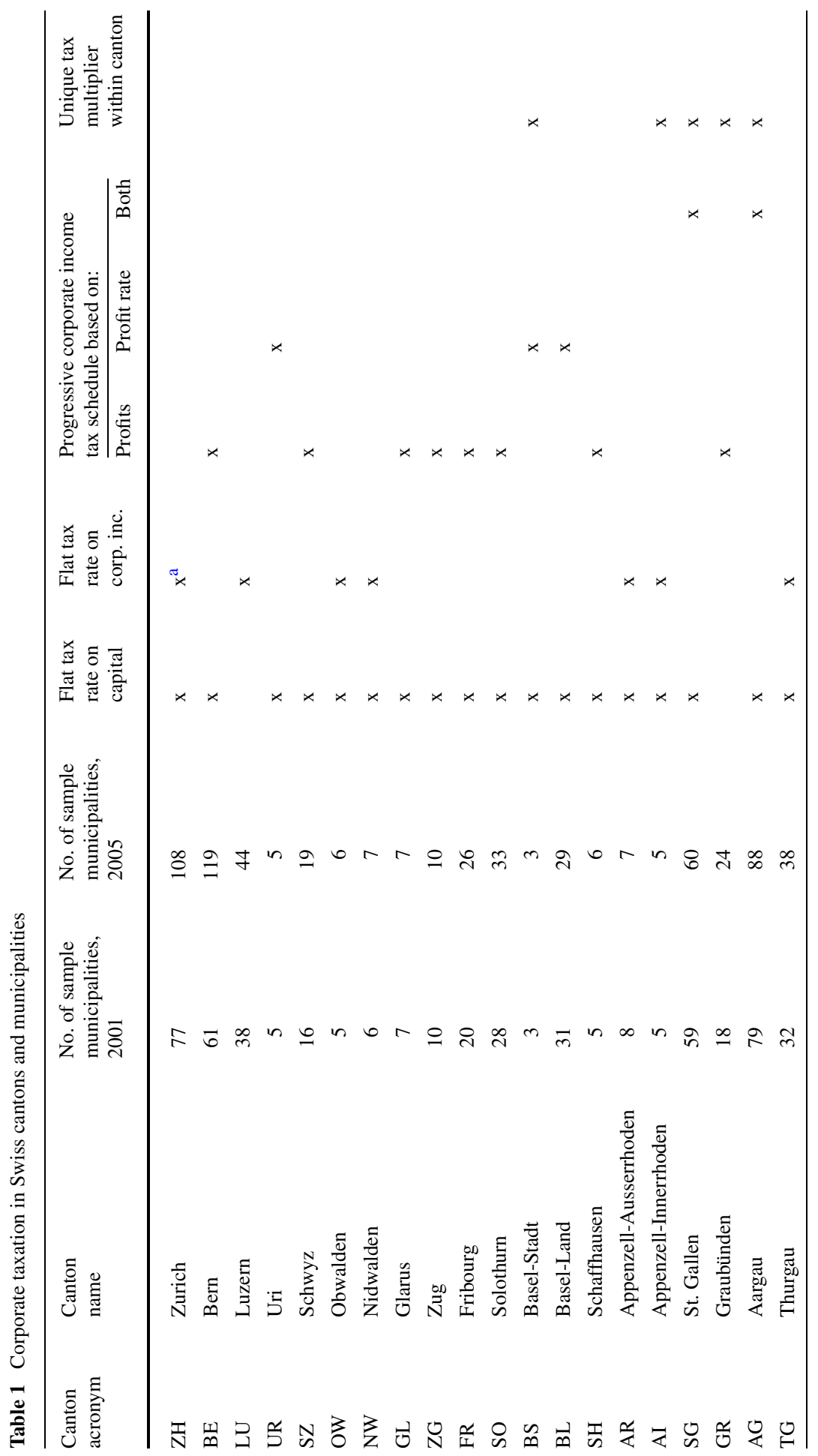




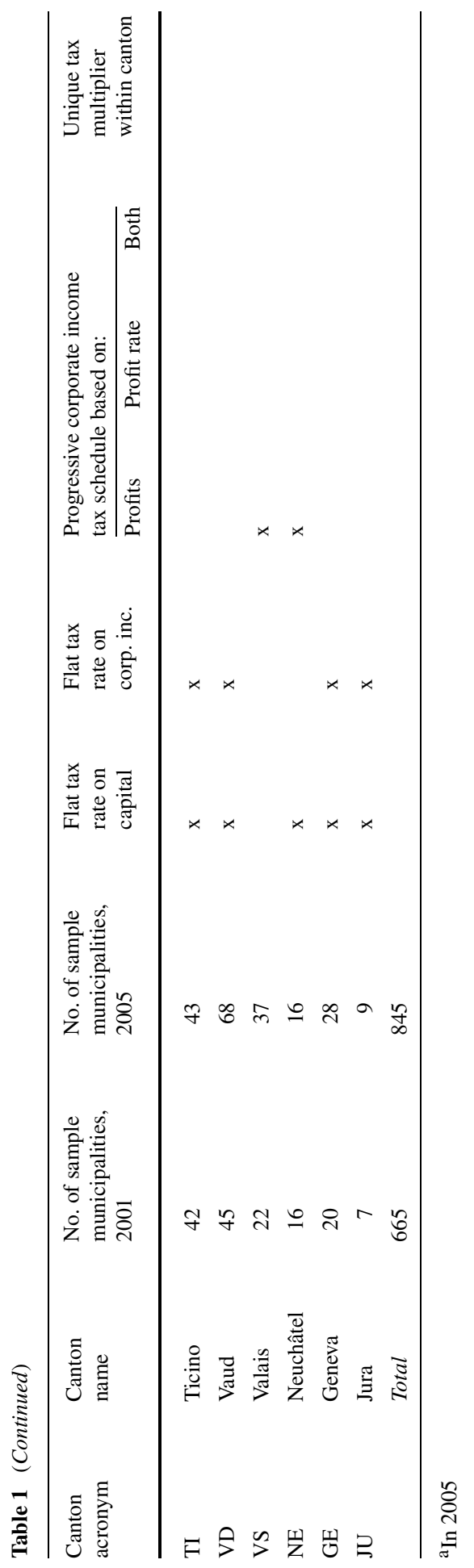


more tax brackets. Additional heterogeneity arises from the fact that some cantons base the calculation of the simple tax on the amount of profits, others on profitability, and some on a combination. Recent changes have without exception been in the direction of flatter tax schedules, as is evident in Fig. 5.

3. Comparable jurisdictions

Switzerland has an area of 41,285 square kilometers and a population of 7.5 million. It therefore covers about twice the area, and hosts roughly the same population, as the US state of Massachusetts. Many hard-to-measure geographical, cultural or political differences that affect international comparisons should not be of much concern in a study across jurisdictions at such a small spatial scale. In addition, institutional features such as the social security system, unemployment insurance and health insurance are either governed by federal law or substantively harmonized across cantons.

As our interest is in differential firm birth rates as a function of differences in tax schedules, we need to ascertain that corporate income taxes indeed affect these firms. In Switzerland, distributed profits are taxed twice, first at the level of the firm, through the corporate income tax, and then at the level of the individuals receiving dividend payments, through the personal income tax. When a profitable firm's owners are also their employees - a frequent occurrence in startup firms - then these owners have an incentive to declare these profits as wages in order to avoid the corporate income tax. If there were no limits to this practice, the corporate income tax would become largely irrelevant for firms run by owner-employees. Swiss fiscal law, however, explicitly bans the "disguised" distribution of profits via inflated wages, and jurisprudence consistently applies the "arm's-length principle", whereby wage payments to owner-employees have to conform to standard remuneration levels in the given occupation and sector. ${ }^{22}$ Therefore, corporate income taxation is of relevance also to small owner-run firms.

\subsubsection{Variables used}

Our study is based on a municipality-sector level panel data set for the five years from 2001 to 2005 . The number of municipalities for which we have the required tax data ranges from 665 in 2001, covering 72 percent of the Swiss population, to 846 in 2005 , covering 83 percent of the population. ${ }^{23}$ Sectors are defined according to the two-digit level of Eurostat's NACE classification, which distinguishes 51 sectors. $^{24}$ Table 2 lists our variables and data sources, Table 3 reports summary statistics.

\footnotetext{
${ }^{22}$ See Henneberger and Ziegler (2008).

${ }^{23}$ The average population of our sample municipalities was 7,928 in 2001 and 7,243 in 2005. These municipalities were host to 85 (89) percent of all new firms in 2001 (2005). The data cover roughly the upper size quartile of Swiss municipalities. Tax data for smaller municipalities are not collected centrally.

${ }^{24}$ A more sectorally disaggregated approach is not possible since our data on the distribution of profits and capital are available at the two-digit level only. We were forced to omit four sectors, for which no firm births were observed in our sample period: NACE 10 (coal mining), 12 (ore mining), 13 (uranium mining) and 23 (coke, refined petroleum and nuclear fuel). We also had to drop NACE 16 (tobacco) due to missing wage data. We therefore work with 46 sectors throughout.
} 

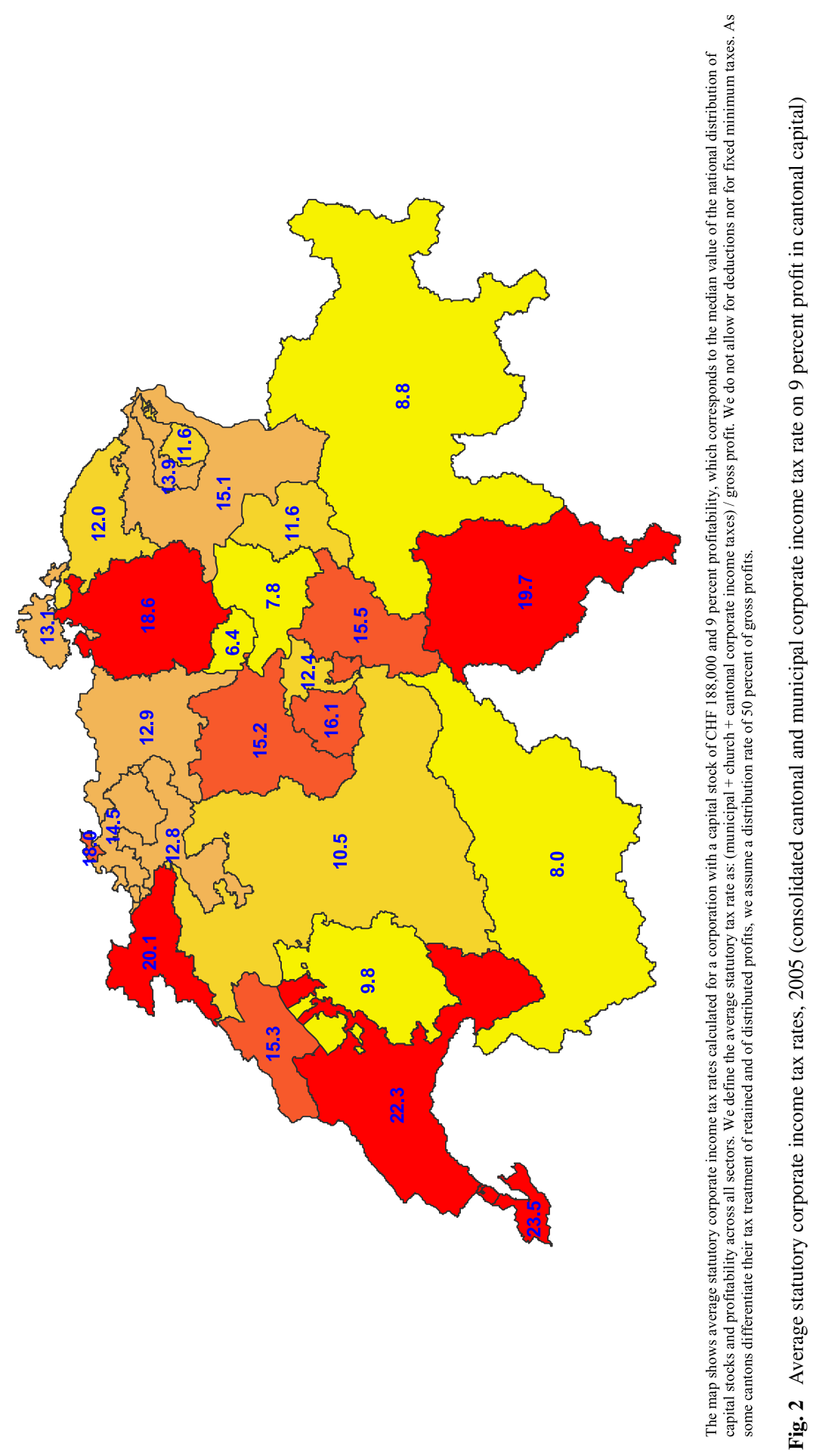


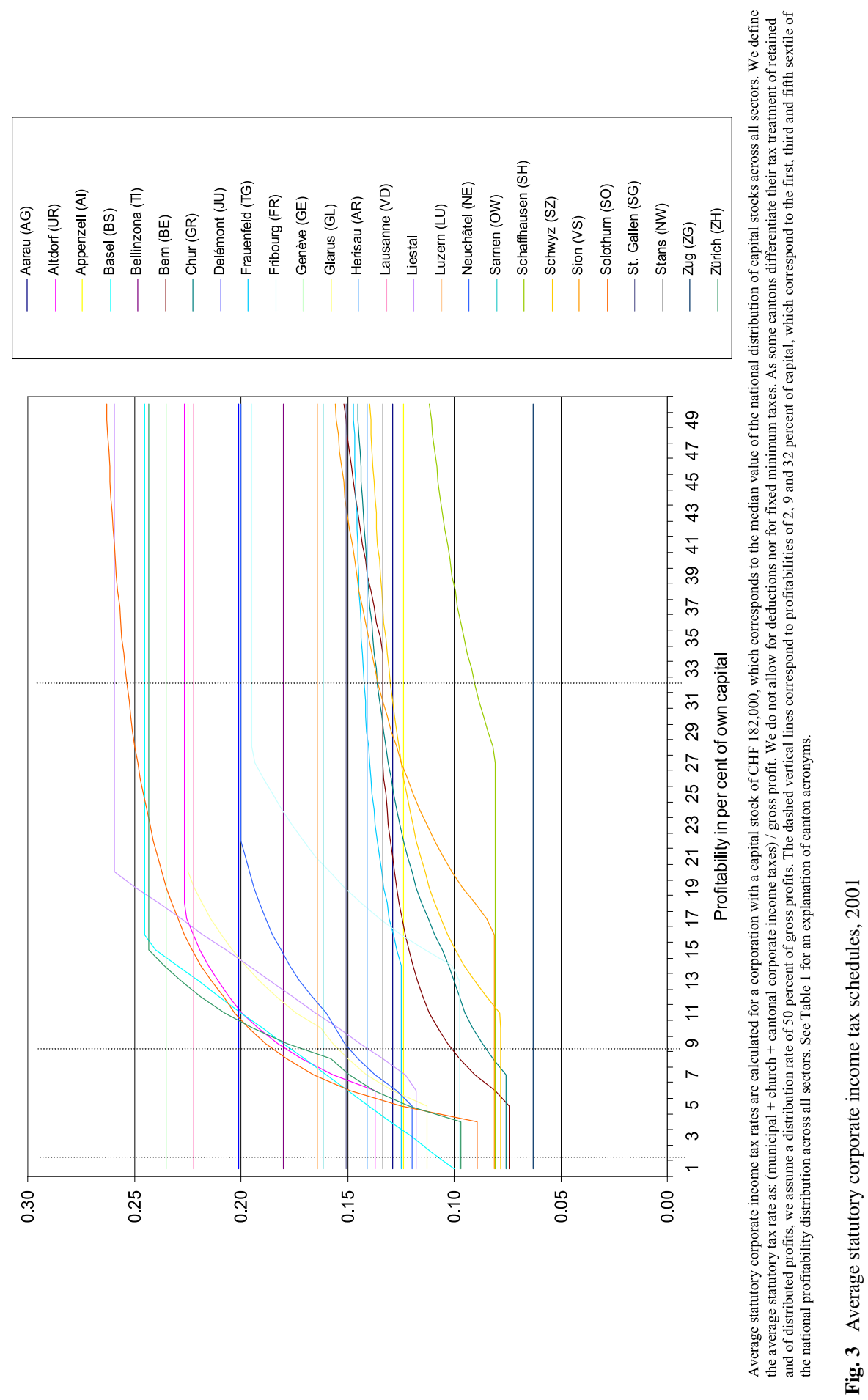




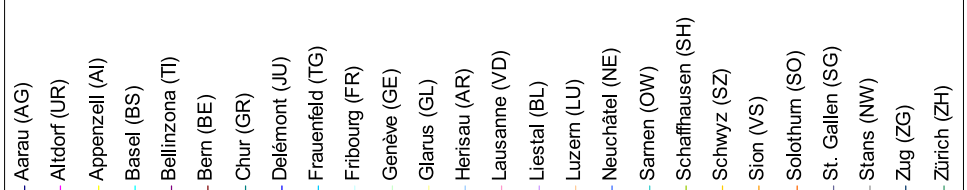

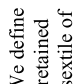

30

害专

的㱐

能希

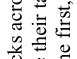

要这

政密

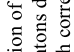

言

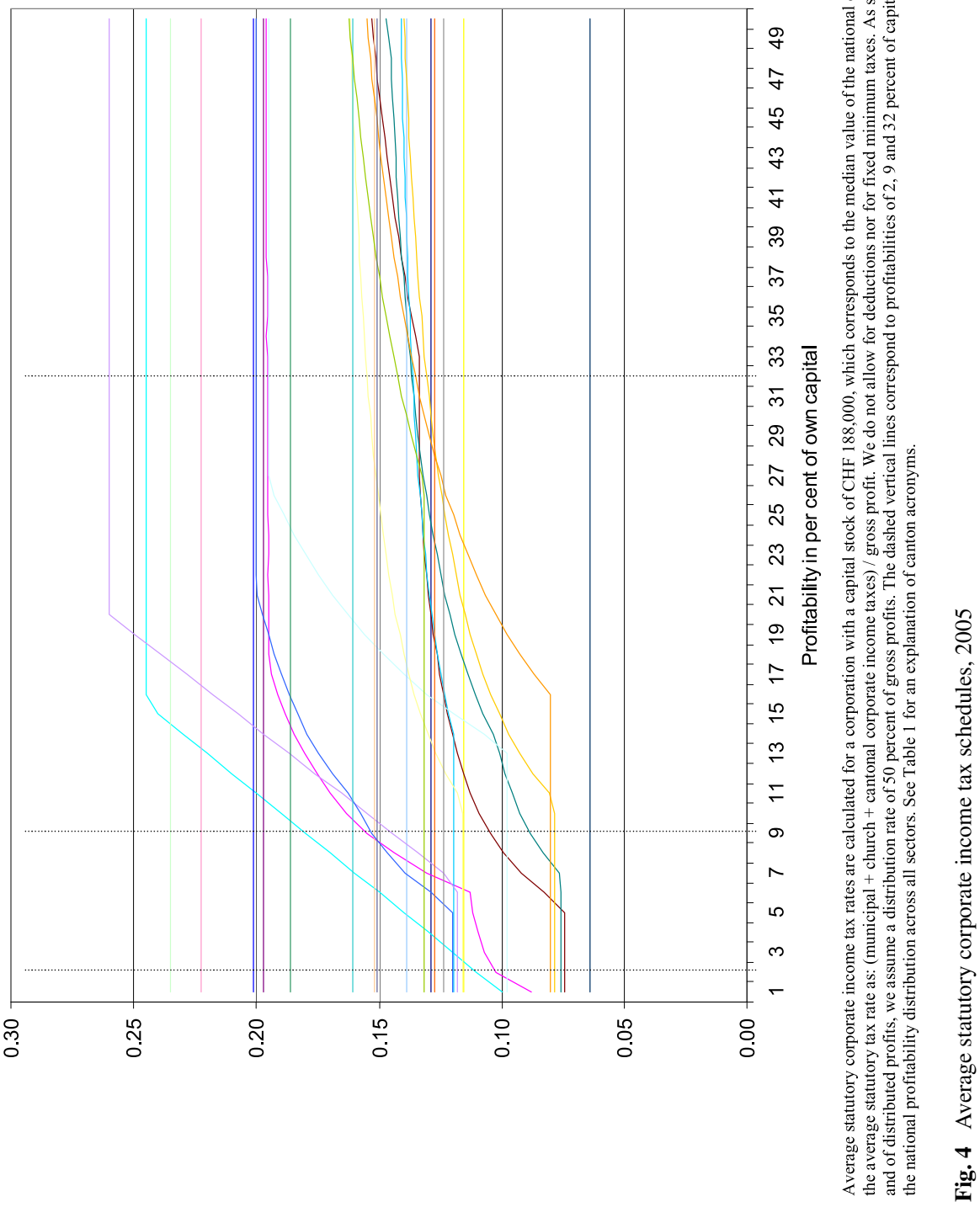



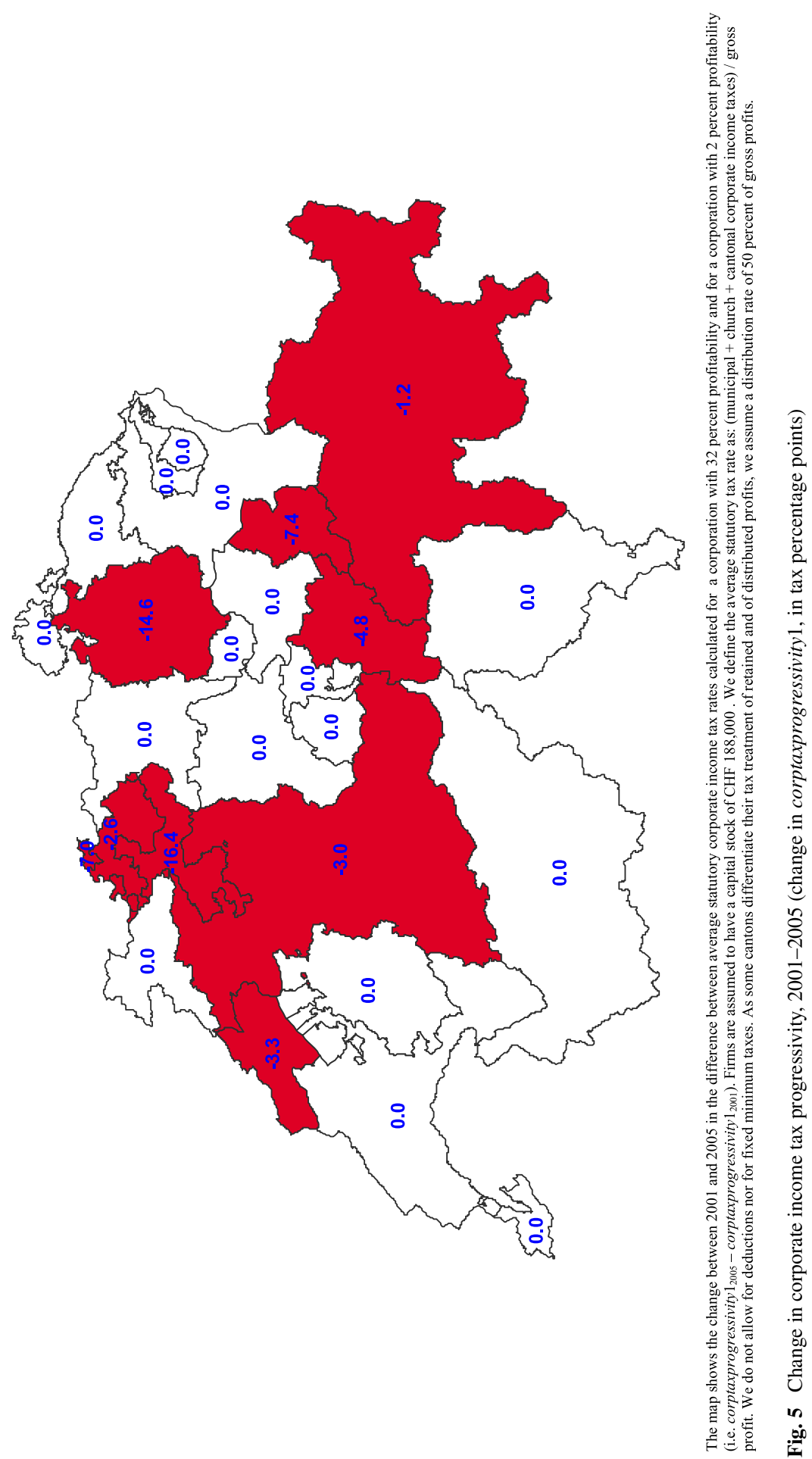
Table 2 Data sources

Dependent variables

newfirms

newjobs

Corporate tax variables

corptaxlevel

corptaxprogressivity 1-3

risk

corptaxbrackets

corptaxwordcount

captaxlevel

dividendprovision

Personal tax variables

incometaxlevel

incometaxprogressivity1-3

wealthtaxlevel

inheritancetax

Other control variables

publicexp

wage

propertyprice

disthighway

distairport

distuniversity

unemployment

munsize
Swiss Federal Statistical Office (UDEMO database)

Swiss Federal Statistical Office (UDEMO database)

Own calculations, based on statutory tax data from the official compendium of cantonal tax laws (Steuern der Schweiz, editions 2001-2005), on cantonal and municipal tax multipliers obtained from the 26 cantonal tax authorities, and on sectoral profitability data for 2004 obtained from the tax authorities of the canton of Aargau

Own calculations, based on statutory tax data from the official compendium of cantonal tax laws (Steuern der Schweiz, editions 2001-2005), on cantonal and municipal tax multipliers obtained from the 26 cantonal tax authorities, and on national profitability data published by the Swiss Federal Finance Administration

Own calculations, based on sectoral profitability data for 2004 from the tax authorities of the canton of Aargau

Own calculations, based on statutory tax data from the official compendium of cantonal tax laws (Steuern der Schweiz, editions 2001-2005)

Own calculations, based on the official compendium of cantonal tax laws (Steuern der Schweiz, editions 2001-2005)

Own calculations, based on statutory tax data from the Swiss Federal Tax Administration and on sectoral profitability data provided by the tax authorities of the canton of Aargau

Official compendium of cantonal tax laws (Steuern der Schweiz, editions 2001-2005)

Effective average tax rates published by the Swiss Federal Tax Administration

Own calculations, based on effective average tax rates published by the Swiss Federal Tax Administration

Effective average tax rates published by the Swiss Federal Tax Administration

Official compendium of cantonal tax laws (Steuern der Schweiz, editions 2001-2005)

Swiss Federal Department of Finance

Swiss Federal Statistical Office

Wüest \& Partner

Swiss Federal Statistical Office

Swiss Federal Statistical Office

Swiss Federal Statistical Office

State Secretariat for Economic Affairs

Swiss Federal Statistical Office

Note: For details on the construction of the variables, see Sect. 4.3.2 


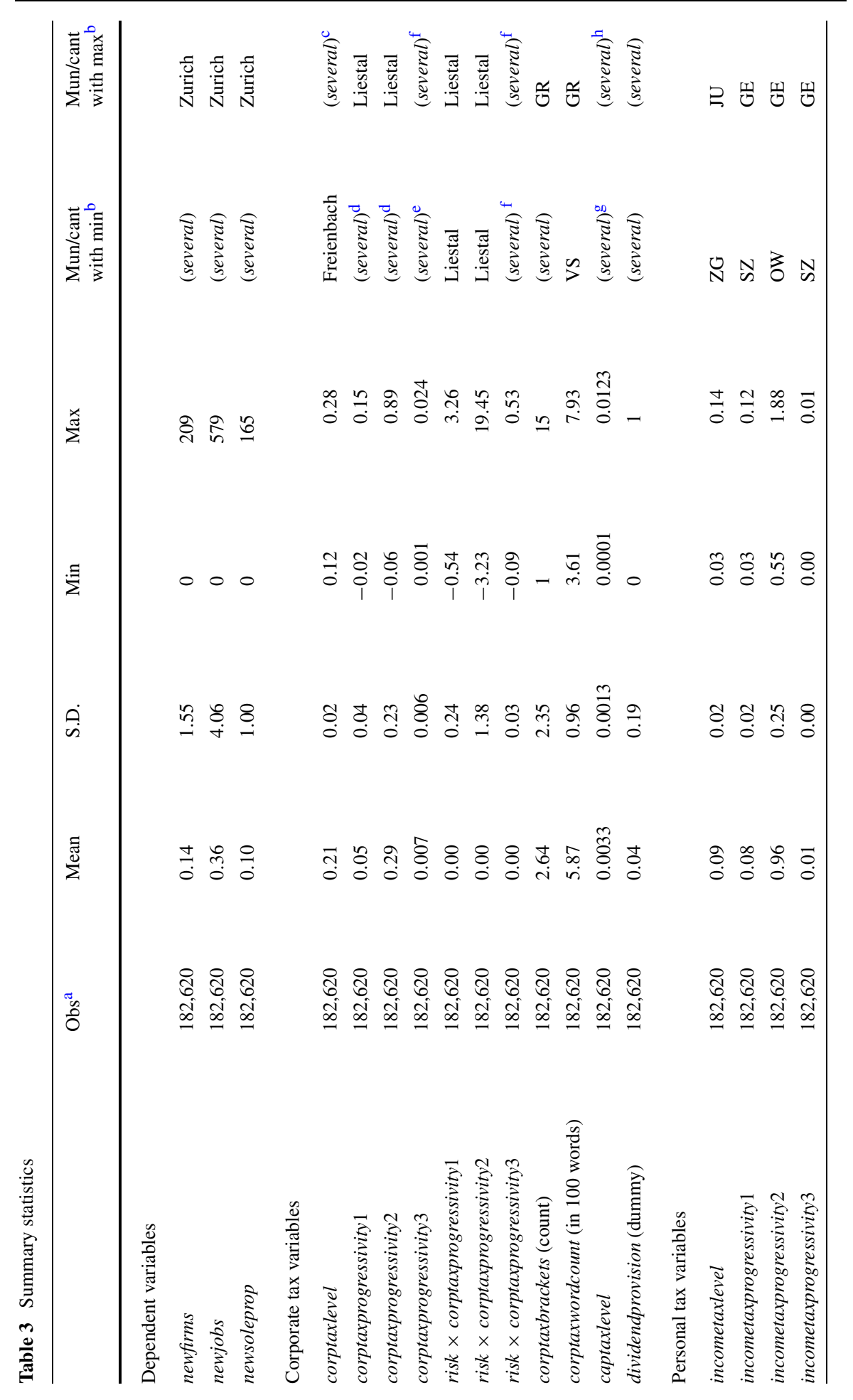




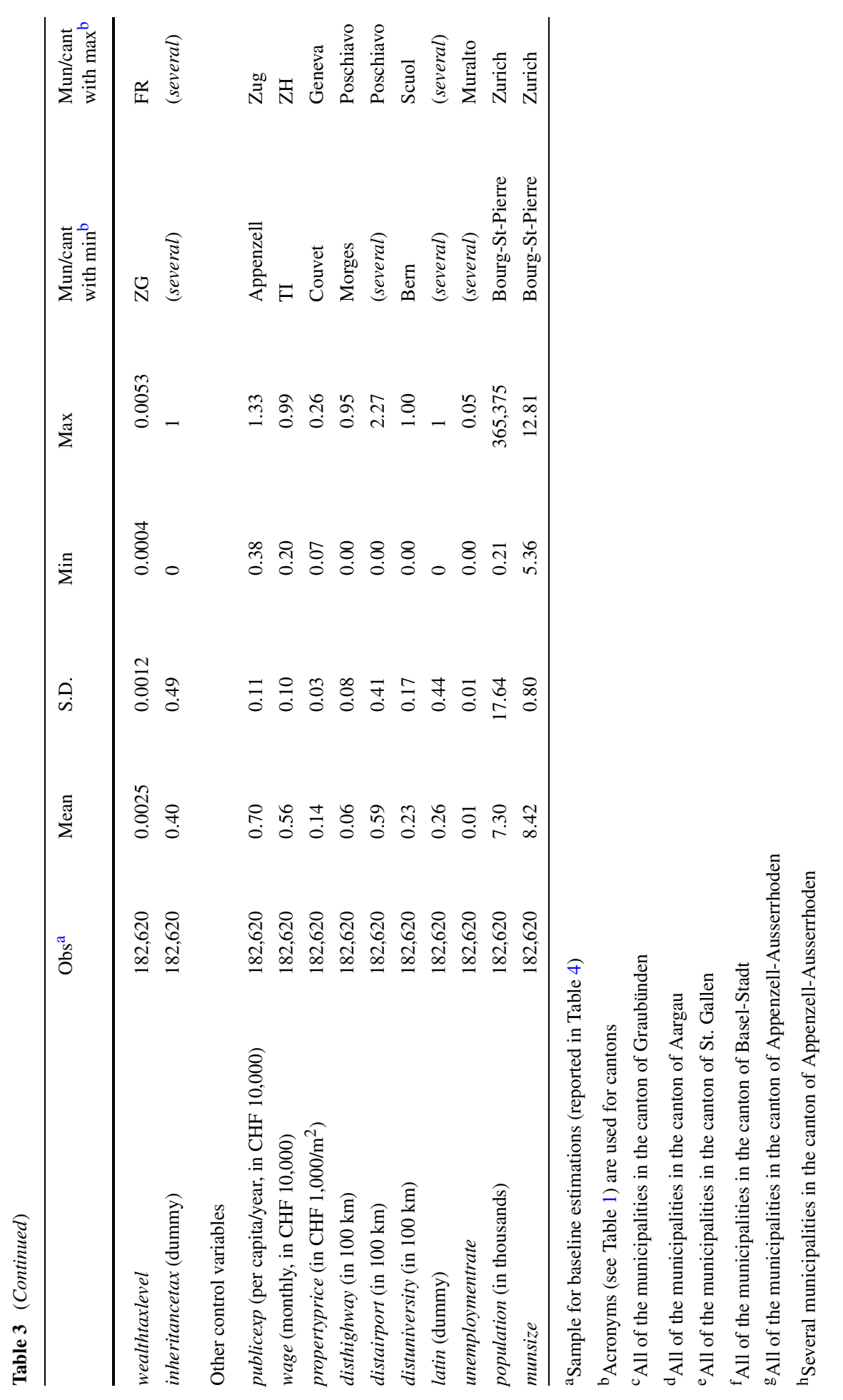


Our dependent variable, newfirms, is the count of new firms per municipality, sector and year. The alternative dependent variable, newjobs, is the count of full-time and part-time jobs created by those new firms. The data set covers all new firms created in Switzerland between 2001 and 2005. The average new firm has 2.6 employees at birth, and 43 percent of new firms have a single employee. Using newjobs as an alternative regressand may be useful by reducing the weight of one-person firms in driving our results. Firms are defined as market-oriented incorporated organizations that are operating for at least 20 hours per week. New entities created by mergers, takeovers, breakups or changes of legal form are not counted. Foreign firms' first subsidiary in Switzerland, however, is considered a new firm. This provides us with data for 25,419 new firms and 64,927 new jobs created over the sample period.

The main component of the explanatory part of our model are corporate tax burdens. In order to construct sector-specific representative corporate tax rates, we first need data on representative profits and capital stocks. While nation-wide statistics exist neither at the level of firms nor at the level of sectors, we can draw on a firmlevel data set for one of the 26 cantons (Aargau). This data set, obtained from the cantonal tax authority, reports pre-tax profits and capital bases for 2004. It covers the universe of 15,731 firms based in that canton, which represents 11 percent of Swiss firms in 2004. We have several reasons to be confident that the micro data for Aargau are representative of patterns for Switzerland at large. First, the overall distribution of firm-level profits in that canton closely matches that for the whole country. ${ }^{25} \mathrm{Sec}$ ond, the corporate tax burden in the canton of Aargau, computed by the federal tax administration, is very close to the national average. ${ }^{26}$ Third, Aargau's sectoral composition is very close to the national average. The correlation between the share of NACE two-digit firms in Aargau and the corresponding national total 0.99 (data from the 2001 establishment census). Finally, Aargau is quite representative also in terms of urbanization - probably the most important covariate of firm structure. According to federal statistics, the proportion of Aargau residents living in urban areas was 0.58 in 2001. The corresponding national share was 0.68. Given that the standard deviation of these shares across cantons was 0.20, Aargau is close to the middle of the distribution in this respect as well.

From the Aargau data we can compute average profits, average capital stocks and average profitability for corporations with positive profits per two-digit sector.

Based on these data, we then construct sector-specific corporate income tax measures.

\footnotetext{
${ }^{25}$ The first, third and fifth sextiles for pre-tax rate of returns are 3, 12 and 37 percent (canton of Aargau) against 2, 9 and 32 percent (Switzerland). The quantiles for Aargau are based on firm-level reported profit data, whereas the national quantiles are calculated using the national profit and capital distributions published by the Federal Tax Administration.

${ }^{26}$ The index of the corporate income tax burden computed by the Federal Tax Administration for the year 2004 has a value of 97.4 for the canton of Aargau. The national average is 100, with values ranging from 57.3 (Schwyz) to 126.7 (Geneva). Aargau levies a minimum corporate tax of 500 Swiss francs ( $\approx 500$ US dollars) on profits and capital together. Therefore, to calculate sector averages, we excluded all observations with a simple tax of 500 francs, even if they declared positive but very low profits. Furthermore, we considered observations with an implied pre-tax rate of return of more than 200 percent to be unreliable and excluded them.
} 
- Level of the corporate income tax (corptaxlevel): Based on statutory tax rates and estimated industry-level average profits and capital stocks, we calculate the industry-specific effective average tax rate (EATR) on profits for all sample municipalities and years. ${ }^{27}$

- Progressivity of the corporate income tax (corptaxprogressivity): Based on the national distribution of capital and profitability across all sectors, we collected tax rates for first, third and fifth sextile profitability firms, characterized by profits amounting to 2, 9 and 32 percent, respectively, of own capital. ${ }^{28}$ This was done separately for three capital levels, representing the first, second and third quartile of the distribution of capital. Our three alternative progressivity measures are then computed as weighted averages across the three representative capital levels. ${ }^{29}$ The first progressivity measure, corptaxprogressivity 1 , is the difference between the EATR for firms with high (32 percent) and low ( 2 percent) profitability. The second progressivity measure, corptaxprogressivity2, corrects for the tax level: we divide corptaxprogressivity 1 by the arithmetic mean of the EATR for firms with low, median and high profitability. A third measure of progressivity, corptaxprogressivity3, measures the redistributive impact of a given tax schedule compared with a proportional tax. By construction, this index ranges from -1 to +1 . A value of corptaxprogressivity $3>0(<0)$ indicates a progressive (regressive) tax system, while corptaxprogressivity $3=0$ stands for a proportional system. ${ }^{30}$ These three measures are highly but not perfectly correlated, with correlation coefficients ranging from 0.89 to 0.98 .

- Industry-specific risk (risk): In accordance with Condition 2, we define risk as the standard deviation of industry profits, expressed as a deviation from the crosssector average standard deviation (risk therefore has mean zero), and based on the

${ }^{27}$ The Swiss corporate tax system allows corporations to deduct actual tax payments from their pre-tax income. Therefore, our EATRs are defined as $\frac{t^{\pi}\left(\pi-t^{K} K\right)}{\left(1+t^{\pi}\right) \pi}$, where $\pi$ denotes pre-tax profits, $K$ is own capital, $t^{\pi}$ is the statutory corporate income tax rate and $t^{K}$ is the statutory capital tax rate.

${ }^{28}$ Due to some small cell sizes, the Aargau data do not allow us to calculate sufficiently reliable sector-level distributions. We therefore prefer to rely on frequency distributions for Switzerland as a whole (available aggregated across sectors) for the profitability dispersion measure.

${ }^{29}$ The weights applied are 0.375 for the cases of low and high capital and 0.25 for the median-capital case, thus taking into account that the low and high cases refer to the upper end of the first and third quartile, respectively. The fact that two of our progressivity measures have negative minima (see Table 3 ) is explained by one canton (Aargau) applying a fixed minimum tax of CHF 500 on all incorporated firms, which implies regressive taxation for certain small firms with low profitability. Furthermore, the definition of EATRs implies that there is some small within-canton variation in progressivity even though municipalities apply a single multiplier to the canton-level tax schedule. Eliminating this variation by taking averages of the progressivity measures within each canton and year has no discernible impact on our results.

${ }^{30}$ This measure is known as a "relative share adjustment" (see, e.g., Kesselman and Cheung 2004). It is a weighted average of a local index of tax progressivity, $R S A_{k}$, where $R S A_{k}=\frac{1-A T R_{k}}{1-A T R}-1$. ATR $R_{k}$ is the average tax rate for the $k$ th income group, and $A T R$ is the aggregate average tax rate. $R S A_{k}$ has an intuitive interpretation, since it can be used to calculate the gain or loss to a specific income group of switching to a fully proportional tax. For example, if $R S A_{k}=0.03$, a $k$-type taxpayer would suffer an income loss of 3 percent if the existing system were replaced by a proportional tax. The global index of progressivity, $R S A_{G}$, is then calculated as follows: $R S A_{G}=\sum_{k=1}^{K} \phi_{k} R S A_{k}$, where $\phi_{k}=\theta_{k}\left(\theta_{k}+2 \sum_{l=k+1}^{K} \theta_{l}\right)$, and $\theta_{k}=\frac{w_{k}}{\sum_{k=1}^{K} w_{k}}$ is post-tax income share of the $k$ th taxpayer ( $w_{k}$ being post-tax income of the $k$ th taxpayer). 
firm-level data for Aargau. This variable is then interacted with the three measures of corporate tax progressivity to provide a test of Proposition 2.

- Complexity of the corporate income tax schedule (corptaxbrackets): Following Slemrod (2005), we define corptaxbrackets as the number of different statutory corporate income tax brackets.

- Complexity of the entire corporate tax code (corptaxwordcount): We define this variable as the count of words in the cantonal corporate tax codes. ${ }^{31}$

In our baseline specification, we control for a range of additional potentially relevant tax variables concerning both corporate and personal income (taxcontrols) and for non-tax explanatory variables that are also likely to determine firm birth rates (othercontrols). The list of those variables is given in Appendix B.

\section{Results}

\subsection{Baseline estimates}

We estimate equation (3) using fixed effects Poisson regression with two-way clustered standard errors. Table 4 reports the baseline estimations for six different variants of our empirical model.

Our results are reassuringly consistent across specifications: all corporate tax variables and all statistically significant controls retain their sign across the six regression runs. Whether we define our dependent variable as counts of new firms (columns 1-3) or as counts of jobs created by those new firms (columns 4-6), is of little consequence to our estimates. Any observed regularities, therefore, do not seem to be driven by particularly small or particularly large new firms. The estimated coefficient signs generally conform with expectations. Numbers of firm births are relatively high in large municipalities, in municipalities with high (non-transfer) public expenditure and in municipalities with high rates of unemployment (which imply fewer outside options for "latent entrepreneurs"). Conversely, firm birth rates are relatively low in remote municipalities (in terms of distance from the highway network). The one counterintuitive statistically significant result on the control variables concerns property prices, for which we estimate a positive coefficient. This result very likely reflects the fact that property prices correlate with certain relevant but unobserved location-specific features without fully capitalizing them.

Turning to the corporate tax variables, we find confirmation for our main hypotheses.

\footnotetext{
${ }^{31}$ Word counts are based on the official compendium of cantonal tax laws Steuern der Schweiz. This compendium reproduces the content of all cantonal tax laws in a standardized format. It has the advantage of using harmonized terminology and thus allowing meaningful comparisons of word counts. The fact that three Swiss cantons are officially bilingual and have identical tax codes in both French and German allows us to quantify the "excess words" in tax codes due to the French language. In the canton of Berne, the French version of the tax code is 36 percent longer than the German one, and in the cantons of Fribourg and Valais, these differences correspond to 44 and 29 percent, respectively. Thus, the average "surplus word count" due to the French language is 37 percent. Therefore, we divide the word count for Latin cantons by 1.37 (the tax code for the Italian-speaking canton of Ticino being recorded in French in the compendium).
} 


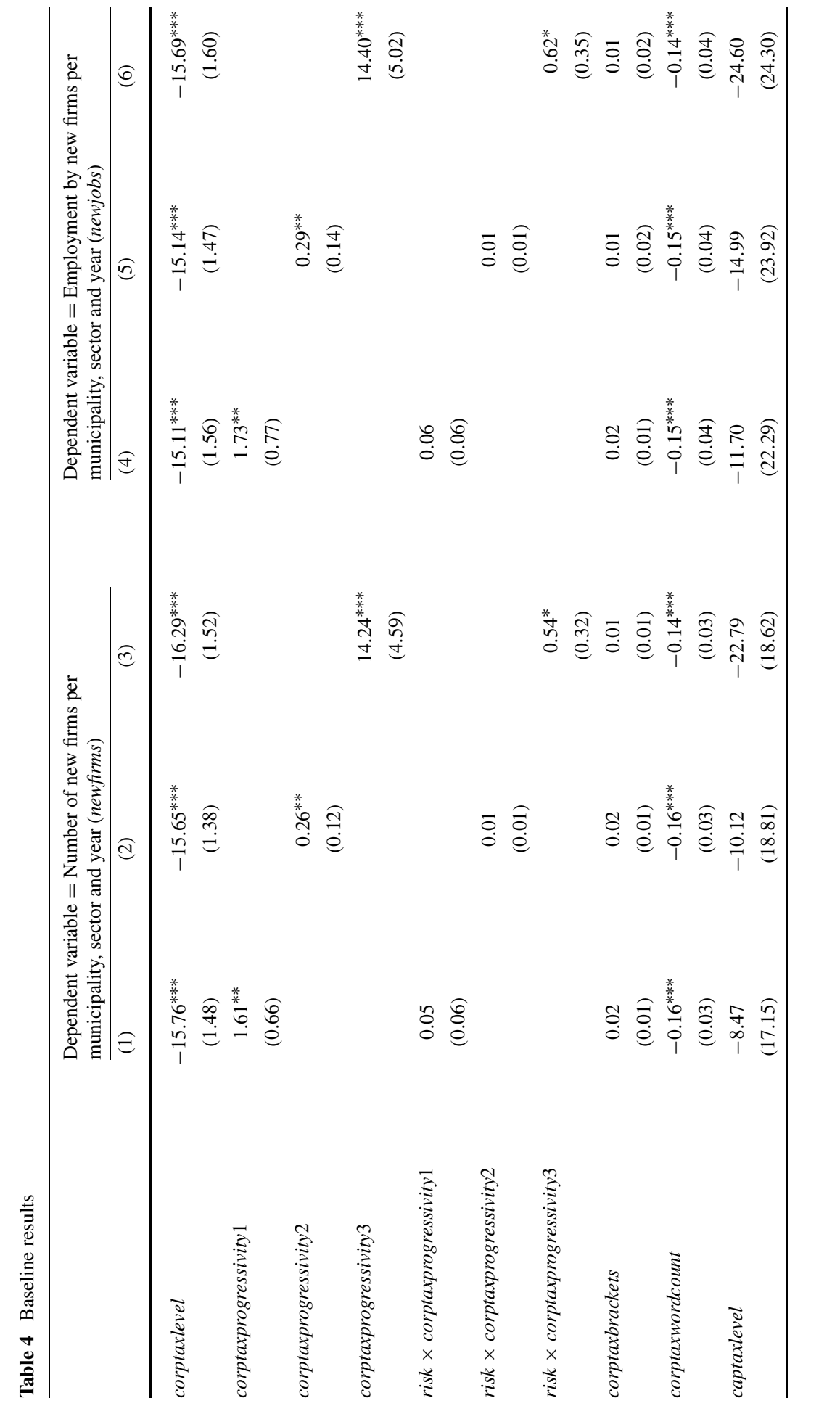




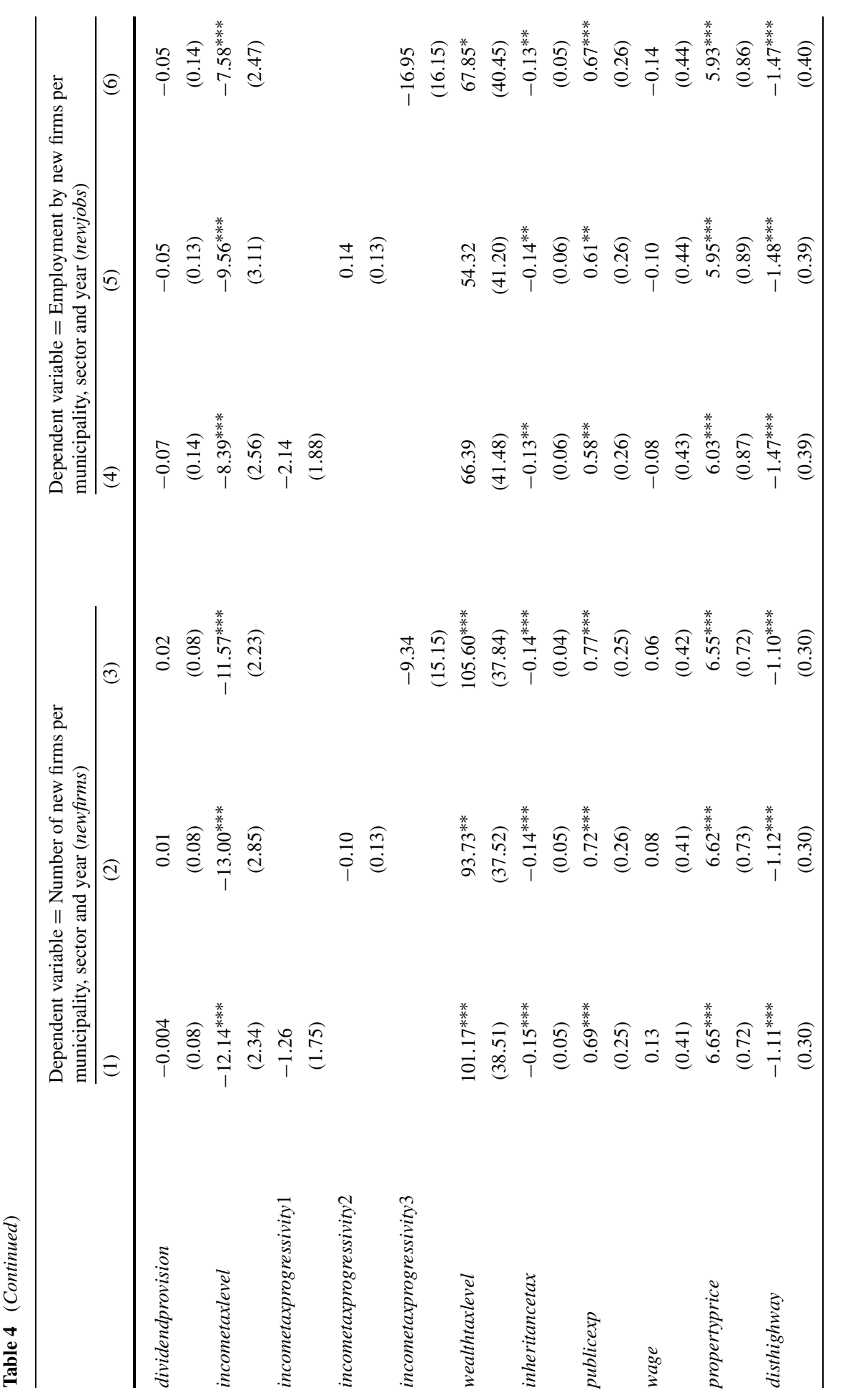




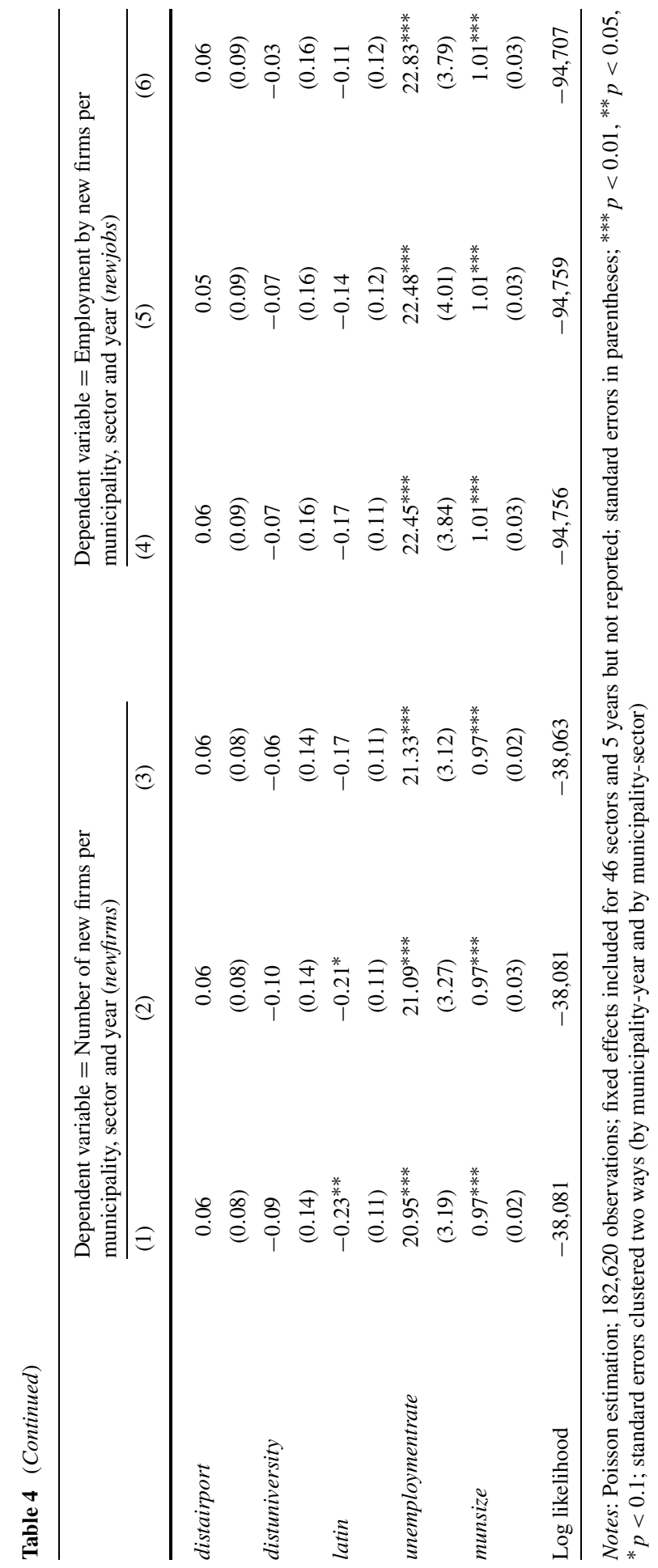


1. The level of taxation has a statistically significantly negative impact, with our corporate income tax variable corptaxlevel returning precisely estimated negative coefficients throughout. The existence of a negative tax level effect is corroborated by the finding that capital taxes (captaxlevel), personal income taxes (incometaxlevel) and inheritance taxes (inheritancetax) also consistently yield statistically negative coefficient estimates. The only exception are wealth taxes (wealthtaxlevel), for which we obtain positive coefficients. A possible explanation for this result is that high wealth taxes act as an incentive for investing in privately held corporations. Overall, however, the conclusion that high average taxes depress firm births is strongly supported.

2. The estimated effects of tax progressivity are positive throughout, in line with our Proposition 1. These coefficients are generally measured somewhat less precisely than those on the tax level variables. Nonetheless, all six coefficients estimated on the variants of corptaxprogressivity are found to be statistically significant at least at the five percent level. Our estimated coefficients on the interactions of corporate income tax progressivity with our proxy measures for sector-specific risk are all positive, which is in line with Proposition 2. Only two of these interaction terms are statistically significant (at the ten percent level), which is very likely due to the inevitably approximate measure of risk in our empirical context. Taken together, these estimates lend support to the prediction that, given a certain expected tax bill, progressivity promotes firm births.

3. We find no significant evidence that the complexity of the corporate income tax schedule itself (corptaxbrackets) affects the rate of firm births. The number of different tax brackets per se therefore seems to be of no consequence for entrepreneurial activity. In contrast, the complexity of the overall corporate tax code, measured via corptaxwordcount, has a statistically significantly negative impact. Hence, entrepreneurship-promoting simplification of corporate taxation would seem to be best achieved not by reducing the number of brackets of the tax schedule but by simplifying the tax code.

Our reported estimates are identified primarily from cross-sectional variation across municipality-sector pairs. We have also experimented with specifications that include municipality fixed effects, thus identifying coefficients from year-on-year changes in regressors. ${ }^{32}$ Given the slow-moving nature of most of our explanatory variables, it is not surprising that these estimates have much lower explanatory power and are mostly statistically insignificant. Interestingly, however, these estimates return statistically significantly positive coefficient estimates on the interaction terms risk $\times$ corptaxprogressivity, thus further corroborating the presence of an insurance effect.

\subsection{Robustness}

In Table 5, we report variations on the baseline estimates of Table 4, in order to gauge their sensitivity. Given the similarity of the two sets of estimates reported in Table 4, we now limit our analysis to specifications with firm counts as the dependent variable.

${ }^{32}$ These results can be obtained from the authors upon request. 
We report estimates for 15 specifications. In the first 12 runs, we alternatively drop variables from the baseline regressions. In columns 1 to 3, we drop the control for the sector-specific expected level of the corporate income tax bill, corptaxlevel. This reverses the sign of the coefficients on corporate tax progressivity, implying a negative effect of progressivity - in line with the "success tax" argument proposed by Gentry and Hubbard (2000, 2005). These estimations show clearly that any verdict on the implications of tax progressivity hinges on whether or not one controls for the expected tax bill.

We also experiment with dropping the two complexity measures, corptaxbrackets (columns 4 to 6) and corptaxwordcount (columns 7 to 9). These changes turn out not to affect any of our coefficient estimates qualitatively, but they strengthen the measured positive impact of corporate tax progressivity. This could suggest that progressivity tends to be associated with more complex tax codes. However, we observe that it is especially the omission of the complexity measure corptaxwordcount that boosts the estimated coefficients on the progressivity measures (columns 7 to 9), although these variables are basically uncorrelated in the raw data. The low bivariate correlations suggest that progressive schedules are perfectly compatible with simple tax codes. The regression results, however, imply that, conditional on other factors, these two variables do comove, and that this comovement to some extent dampens the measured positive effect of corporate tax progressivity.

Next, we drop all variables not related to corporate taxation bar the scaling variable munsize. These results are shown in columns 10 to 12 of Table 5. The signs and significance levels on our coefficients of interest are reassuringly similar to those found for the full model in Table 4. Unlike in the baseline estimations, the impact of capital taxes is now estimated to be statistically significantly negative. The coefficients on corptaxwordcount are up to 40 percent smaller, but they remain statistically significantly negative throughout. Less plausibly, the coefficient on dividendprovision turns statistically significant negative. Our main results, however, do not seem to be driven by the particular set of conditioning variables chosen for the baseline estimations.

As a final robustness test, we replace the dependent variable by the count of new sole proprietorships (newsoleprop), the main legal form of non-incorporated business ventures. ${ }^{33}$ Since these organizations are not subject to corporate taxation, we expect corporate tax-related regressors to have less of an influence. However, we do not expect corporate taxes to irrelevant, as many new firms start out as sole proprietorships with the aim of incorporating later. Hence, rational forward-looking entrepreneurs will be sensitive to corporate taxation even if they choose to operate (initially) as sole proprietorships. This is indeed what we find (see columns 13-15 of Table 5). The level effect of corporate taxes remains statistically significant, but the size of the coefficient shrinks by more than one-half. None of the progressivity variables remains statistically significant. It is furthermore reassuring to note that the coefficients on dividendprovision are statistically significantly negative, indicating that such provisions indeed reduce recourse to non-incorporated organizational forms.

We have conducted a number of additional sensitivity tests not reported here but available on request. The main alternatives we tried were (a) models with newjobs

\footnotetext{
${ }^{33}$ We thank an anonymous referee for suggesting us to consider also non-incorporated organizations.
} 


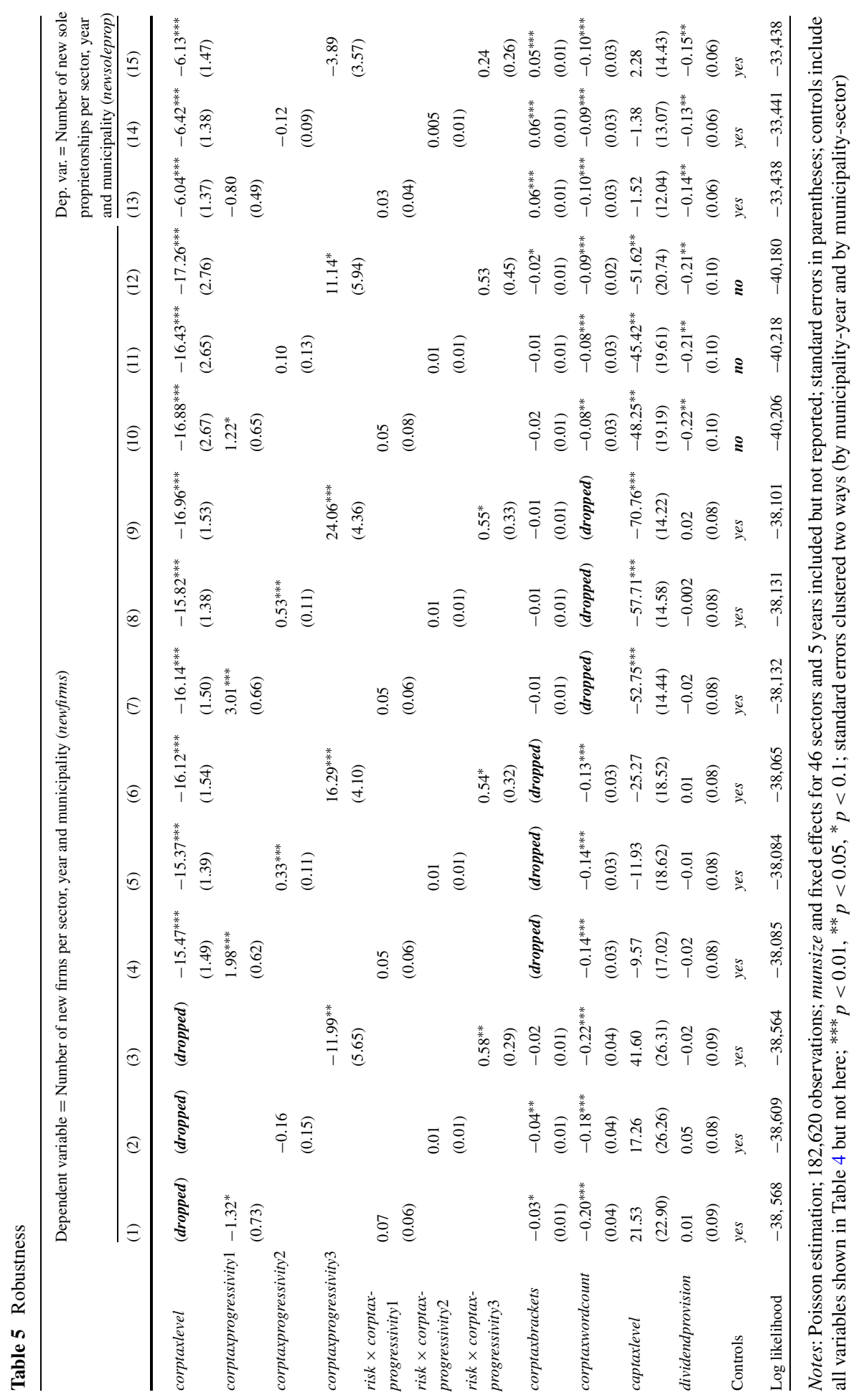


as the dependent variable, (b) models with the coefficient on the exposure variable munsize forced to unity, (c) models with municipality-level fixed effects, (d) models with canton-level instead of municipality-level personal tax variables, (e) models with sector-level coefficient estimates on wage and propertyprice to account for different factor intensities, and (f) models with additional controls (for municipal debt burdens, urban areas, length of lake shores, individual components of public expenditure, and local unemployment rates). To the extent that they were still identified with these alternative specifications, none of our qualitative findings turned out to be affected.

\subsection{Quantitative effects}

Our central research question is qualitative in nature: does corporate tax progressivity promote firm births, given the expected corporate tax bill? The answer appears to be yes. We can go further than this, however, and evaluate the magnitudes of the various determinants of firm births, related to taxes and otherwise. The Poisson coefficients reported so far are semielasticities, measuring the proportionate change in the conditional mean of firm births for a one-unit change in the respective regressor. Since the scales of our regressors differ considerably (see Table 3), these semielasticities are not directly comparable.

In Table 6, we therefore show transformations of the baseline estimates that can be compared across variables. Columns 4 to 6 report elasticities, computed as the product of the Poisson coefficients (columns 1-3) and the means of the relevant regressors (column 10). These numbers give the percentage effect of a one-percent change in the value of the respective regressor. As an alternative, we report semistandardized coefficients in columns 7 to 9, defined as the product of the Poisson coefficients (columns 1-3) and the standard deviations of the relevant regressors (column 11). The semistandardized coefficients quantify the percentage effect of a one-standard-deviation change in the value of the respective regressors.

Both sets of transformed coefficients highlight the importance of taxes for firm births. Of all regressors included in our model, by far the strongest effects are measured for corporate tax levels, with an elasticity of around 3.3 in absolute value. Differences in corporate income tax levels clearly have strong effects on firm formation rates across Swiss municipalities. ${ }^{34}$

Our estimated percentage response of firm births with respect to a percentagepoint change in the corporate tax level (i.e. the implied semi-elasticity) is around -0.2 . This estimate can be compared to related studies that use intra-national data on firm births. Not surprisingly, it is close to that found in Swiss data by Brülhart et al. (2012), whose mean Poisson estimate is -0.3 . It falls between the values found by two other European studies. Using British data, Duranton et al. (2011) detected no statistically significant effect on establishment entry. Rathelot and Sillard (2008), using French data, estimated a semi-elasticity of -1.2 . These differences in estimated elasticities are likely due to differences in tax systems and in definitions of

\footnotetext{
${ }^{34}$ Our estimates suggest a more than proportional reaction of firm births to changes in corporate tax levels. It would of course be erroneous to read into this a potential for revenue-increasing tax cuts, as our model does not capture responses of the entire tax base.
} 


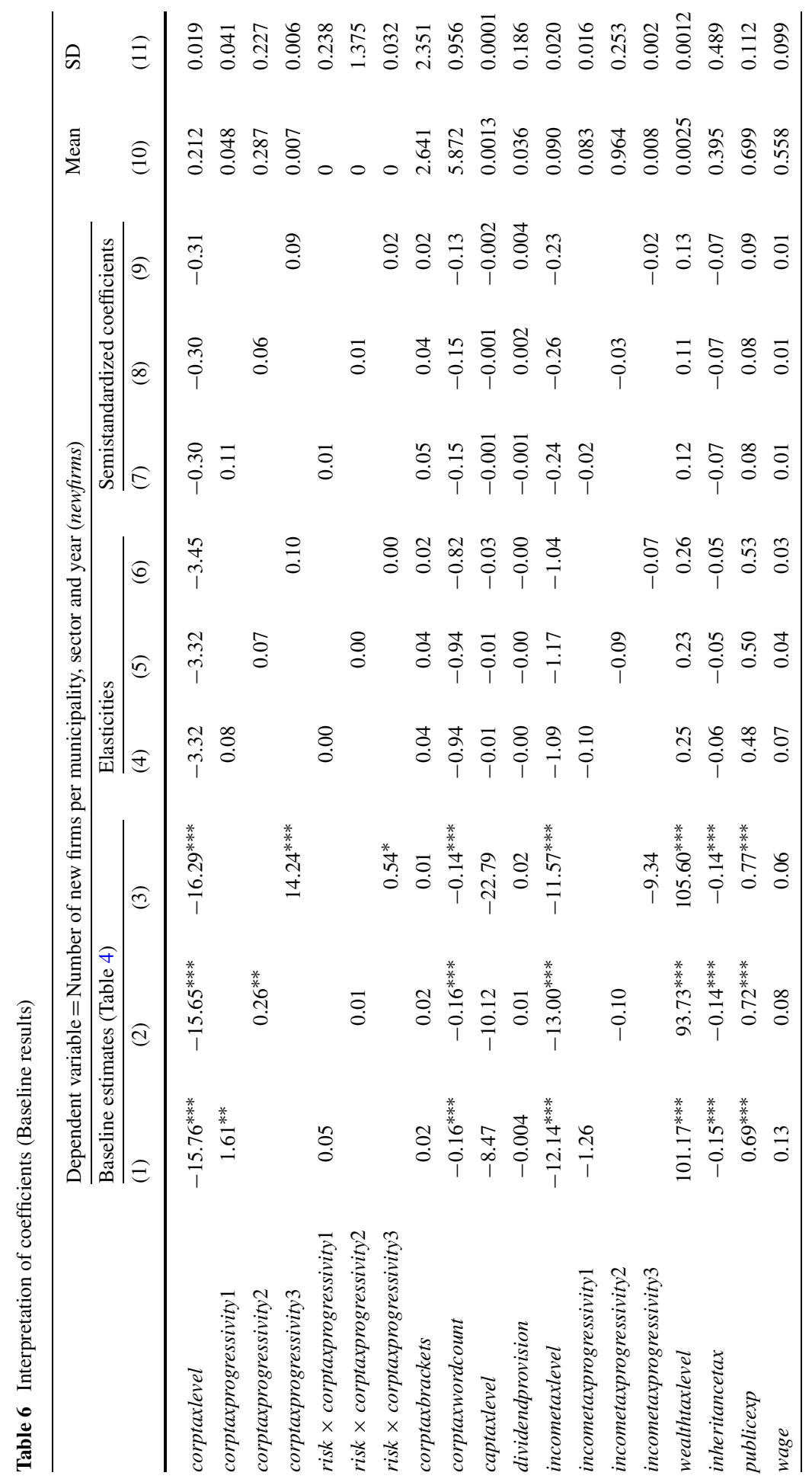




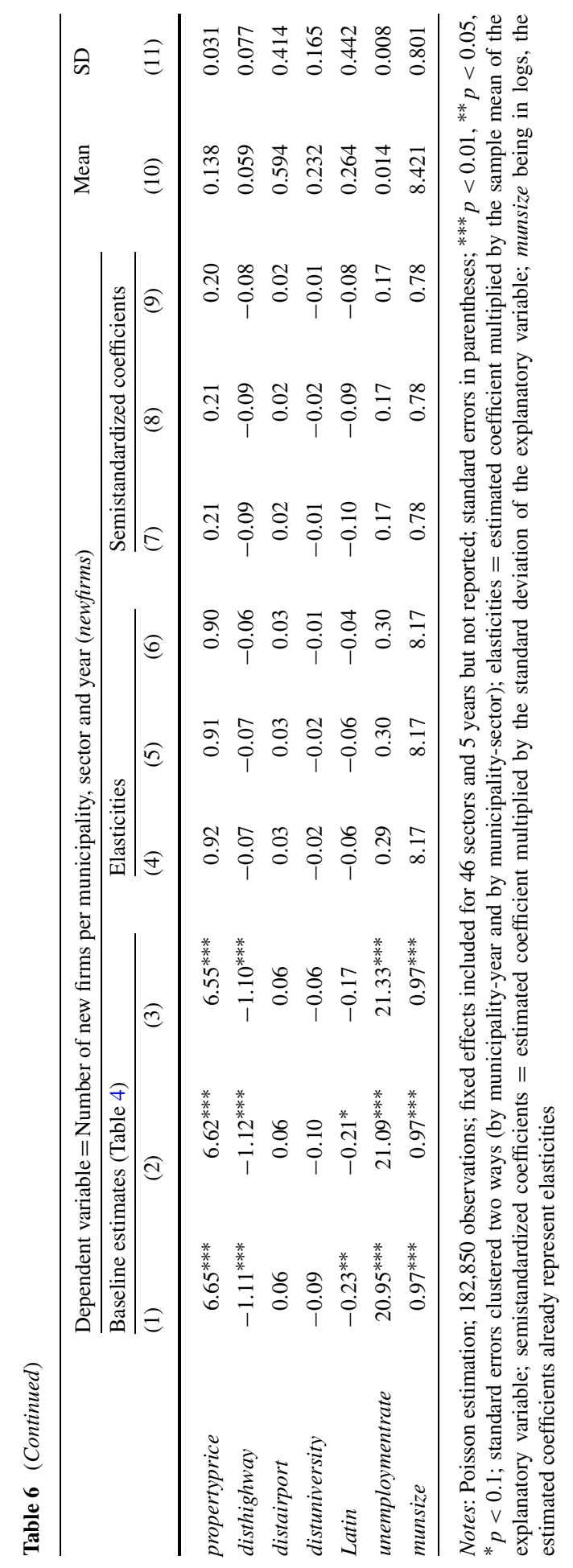


"new firms". In particular, Swiss local corporate taxes are levied on profits while their British and French counterparts are, respectively, levied on property areas and physical capital. Since national corporate taxes are predominantly levied on profits, the Swiss local context arguably offers a better approximation to international corporate tax differentials.

Second to the impact of the expected level of the corporate tax bill comes the impact of the expected level of the personal tax bill, with an elasticity of slightly above 1 in absolute value. Given the difficulty of attributing relevant personal tax variables to municipalities (due to commuting), this variable likely suffers from some mismeasurement. This in turn implies attenuation bias for the coefficient estimate, which makes the strong estimated effect of personal taxes all the more noteworthy. The third most important dimension of taxation is the complexity of the corporate tax code (corptaxwordcount), with an elasticity of around -0.9 . All other aspects of the tax code have comparatively minor effects on firm births. The average elasticity with respect to the progressivity of corporate taxes is estimated at around 0.08 -an order of magnitude smaller than the complexity effect. The smallest quantitative effect of all tax variables is found for corptaxbrackets and dividendprovision, with an average elasticity of very close to zero.

In sum, we find a clear hierarchy of tax effects, with tax levels having by far the strongest impact on firm birth rates, the complexity of tax codes coming second, and the progressivity of tax schedules having a comparatively small but statistically significantly positive impact.

\section{Conclusion}

Tax reforms in the spirit of the "flat-tax" model aim to reduce three parameters: the average tax rate, the progressivity of the tax schedule, and the complexity of the tax code. Using data on sub-federal jurisdictions in Switzerland, we estimate the separate effects of these three components of corporate income taxes on the incidence of firm births. Although we work with panel data, the slow-moving nature of the tax variables implies that identification is based mainly on cross-sectional variation.

Our results confirm that lower average tax rates and reduced complexity of the tax code promote firm births. Controlling for these effects, we find evidence that reduced progressivity inhibits firm births. Our reading of this result is that tax progressivity has an insurance effect that facilitates entrepreneurial risk taking. ${ }^{35}$

The positive effects of lower tax levels and reduced complexity are estimated to be significantly stronger than the negative effect of reduced progressivity. To the extent that firm births reflect desirable entrepreneurial dynamism, it is not the flattening of tax schedules that is key to successful tax reforms, but the lowering of average

\footnotetext{
${ }^{35}$ An alternative interpretation could be that new firms prefer more progressive tax schedules, given an expected tax bill, because they are credit constrained: the lower tax liability in case of a bad profit outcome may offer a greater gain in terms of access to external funding than the loss implied by a higher tax liability in case of a good outcome. See Keuschnigg and Ribi (2009) for a model of corporate income taxation with credit-constrained firms.
} 
tax burdens and the simplification of tax codes. ${ }^{36}$ Flatness per se is of secondary importance and even appears to be detrimental to firm births.

Acknowledgements We thank the editor (Dhammika Dharmapala), two anonymous referees, Thiess Buettner, Mario Jametti and seminar participants at the University of Barcelona (IEB) for helpful comments; and Roland Aregger (Aargau tax authority), Andrea Grossi (Federal Statistical Office), Dieter Marmet (Wüest \& Partner), Raphaël Parchet and Werner Tanner (State Secretariat for Economic Affairs) for the generous provision of data. Financial support from the EU's Sixth Framework Programme ("MicroDyn"project) and from the Swiss National Science Foundation (grants 612-065970, CRSI11_130648 and "NCCR Trade") is gratefully acknowledged.

\section{Appendix A: Proof of Proposition 2}

From (1) and (2) it follows that

$$
\frac{\partial \pi_{L}}{\partial \pi_{H}}=-\frac{p_{H}}{p_{L}}
$$

and

$$
\frac{\partial k_{L}}{\partial \pi_{H}}=-\frac{\Pi p_{H} k_{H}}{\left(\Pi-p_{H} \pi_{H}\right)^{2}} .
$$

Then Proposition 1 and (4) and (5) imply

$$
\begin{aligned}
& \frac{\partial^{2} \Delta E U(w)}{\partial k_{H} \partial \pi_{H}}=-p_{H} \Delta U_{w}\left(w^{p r o g}\right) \\
& -p_{H} \pi_{H}\left[\begin{array}{c}
U_{w w}\left(w_{H}^{p r o g}\right)\left[1-t-k_{H}\right] \\
-U_{w w}\left(w_{L}^{p r o g}\right)\left[-\frac{\partial k_{L}}{\partial \pi_{H}} \pi_{L}+\left[1-t-k_{L}\right] \frac{\partial \pi_{L}}{\partial \pi_{H}}\right]
\end{array}\right] \\
& =-p_{H} \Delta U_{w}\left(w^{\text {prog }}\right) \\
& -p_{H} \pi_{H}\left[\begin{array}{c}
U_{w w}\left(w_{H}^{p r o g}\right)\left[1-t-k_{H}\right] \\
-U_{w w}\left(w_{L}^{p r o g}\right)\left[\begin{array}{c}
\frac{\Pi p_{H} k_{H}}{\left(\Pi-p_{H} \pi_{H}\right)^{2}} \frac{\Pi-p_{H} \pi_{H}}{p_{L}} \\
-\left[1-t+\frac{p_{H} \pi_{H}}{\Pi-p_{H} \pi_{H}} k_{H}\right] \frac{p_{H}}{p_{L}}
\end{array}\right]
\end{array}\right] \\
& =-p_{H} \Delta U_{w}\left(w^{\text {prog }}\right) \\
& -p_{H} \pi_{H}\left[1-t-k_{H}\right]\left[U_{w w}\left(w_{H}^{\text {prog }}\right)+\frac{p_{H}}{p_{L}} U_{w w}\left(w_{L}^{\text {prog }}\right)\right] \\
& >0 \text {, }
\end{aligned}
$$

where

$$
\begin{aligned}
U_{w w}\left(w_{L}^{\text {prog }}\right) & =U_{w w}\left(\left[1-t-k_{L}\right] \pi_{L}\right)<0, \\
U_{w w}\left(w_{H}^{\text {prog }}\right) & =U_{w w}\left(\left[1-t-k_{H}\right] \pi_{H}\right)<0, \\
\Delta U_{w}\left(w^{\text {prog }}\right) & =U_{w}\left(w_{H}^{\text {prog }}\right)-U_{w}\left(w_{L}^{\text {prog }}\right)<0 .
\end{aligned}
$$

\footnotetext{
${ }^{36}$ Firm births in our data could in principle also be the result of "income shifting" from bigger to smaller incorporated units, or through the incorporation of sole proprietorships. Data permitting, it would be interesting in future work to analyze these two margins separately from genuine startup ventures.
} 


\section{Appendix B: Control variables}

The list of baseline explanatory tax variables (taxcontrols) is as follows.

- Level of capital tax (captaxlevel): We calculate an industry-specific EATR on corporate capital for all municipalities and years.

- Provisions to alleviate double taxation of dividends (dividendprovision): Dummy variable which is set equal to 1 if a canton has a reduced tax rate on dividend income and to 0 otherwise.

- Level of the personal income tax (incometaxlevel): The Swiss federal tax administration publishes representative EATRs on personal income for all of the municipalities in our sample. ${ }^{37}$ As we cannot know what municipality the owners of our sample firms reside in, we have considered two hypotheses for all personal taxes: (a) firm owners live in the municipality their firm is located in, or (b) owners live in the canton their firm is located in. Since the results do not differ significantly, we report results based on the second hypothesis. We thus compute incometaxlevel as the weighted average personal income tax burden, using the published cantonal sample mean of the EATR on low, median and high income households (corresponding to the first, third and fifth sextile of the national household income distribution).

- Progressivity of the personal income tax (incometaxprogressivity): Based on the published canton-average EATR on low, median and high income, we define incometaxprogressivity1, incometaxprogressivity 2 and incometaxprogressivity 3 analogously to corptaxprogressivity $1-3$.

- Level of the wealth tax (wealthtaxlevel): We compute this variable as the cantonalaverage EATRs for a person with taxable wealth of 300,000 Swiss francs $(\approx 300,000$ US dollars), which corresponds approximately to the mean wealth level among individuals with non-zero declared wealth over our sample period.

- Inheritance tax (inheritancetax): This variable takes the value of 1 if a canton has an inheritance tax for direct descendants in a given year and 0 otherwise.

The list of baseline non-tax explanatory variables (othercontrols) is as follows.

- Public expenditure (publicexp): Firms not only pay taxes, they may also benefit from public spending. We construct this variable as the sum of municipal and cantonal per-capita public spending, excluding social transfers and deflated with the consumer price index. The public spending items included in publicexp are public administration, security, education, culture and sports, roads, and public transport. $^{38}$

\footnotetext{
${ }^{37}$ The published EATRs correspond to average cantonal, municipal and church tax rates for a representative household (married couple with two children) and for a range of reference incomes.

${ }^{38}$ Annual municipal expenditures are only available for the 26 canton capitals and 16 other municipalities. However, the Swiss Federal Finance Administration publishes overall annual municipal spending for each canton. We compute annual municipal spending for the other municipalities by subtracting the expenditure of the $(26+16)$ municipalities from overall municipal expenditures and then dividing it by the population of the remaining municipalities. Thereby, the remaining municipalities are attributed identical values of publicexp within each canton.
} 
- Wage level (wage): We control for average monthly wages per sector and region, deflated by the consumer price index. ${ }^{39}$

- Property prices (propertyprice): This variable is defined as the unweighted average of median municipality-year-level market prices per square meter of retail space, office space and industrial real estate, deflated by the consumer price index. ${ }^{40}$

- Geography: To capture accessibility (and thus potentially agglomeration effects), we include three additional control variables: disthighway, the road distance from every municipality to the nearest highway access, distairport, the road distance to the nearest international airport, and distuniversity, the distance to the nearest university.

- Culture (latin): We control for potential cultural and attitudinal differences by introducing the dummy variable latin that takes the value of 1 if the main language of a canton is French or Italian and 0 if it is German.

- Unemployment (unemploymentrate): We control for the population share of registered unemployed workers by municipality and year.

- Size of the municipality (munsize): We use the log of the average resident population per year and municipality as the exposure variable.

\section{References}

Ahsan, S. M. (1974). Progression and risk-taking. Oxford Economic Papers, 26, 318-328.

Audretsch, D. B., \& Fritsch, M. (2002). Growth regimes over time and space. Regional Studies, 36(2), $113-124$.

Becker, R., \& Henderson, V. (2000). Effects of air quality regulations on polluting industries. Journal of Political Economy, 108, 379-421.

Brülhart, M., \& Jametti, M. (2006). Vertical versus horizontal tax externalities: an empirical test. Journal of Public Economics, 90(10-11), 2027-2062.

Brülhart, M., Jametti, M., \& Schmidheiny, K. (2012) Do agglomeration economies reduce the sensitivity of firm location to tax differentials? Economic Journal, forthcoming.

Cameron, A. C., \& Trivedi, P. K. (1998). Regression analysis of count data. Cambridge: Cambridge University Press.

Cameron, A. C., Gelbach, J. B., \& Miller, D. L. (2011). Robust inference with multi-way clustering. Journal of Business \& Economic Statistics, 29(2), 238-249.

Carlton, D. (1983). The location and employment choices of new firms: an econometric model with discrete and continuous endogenous variables. Review of Economics and Statistics, 65, 440-449.

Cowell, F. A. (1975). Some notes on progression and risk-taking. Economica, 42, 313-318.

Cullen, J. B., \& Gordon, R. (2006a). Tax reform and entrepreneurial activity. In J.M. Poterba (Ed.), Tax policy and the economy (Vol. 20, pp. 41-71). Cambridge: MIT Press.

Cullen, J. B., \& Gordon, R. (2006b). How do taxes affect entrepreneurial activity? A comparison of U.S. and Swedish law (in Swedish). In P. Braunerhjelm \& J. Wiklund (Eds.), Entreprenörskap och tillväxt (pp. 71-93). Stockholm: Swedish Foundation for Small Business Research.

Cullen, J. B., \& Gordon, R. H. (2007). Taxes and entrepreneurial risk-taking: theory and evidence for the U.S. Journal of Public Economics, 91, 1479-1505.

Da Rin, M., Di Giacomo, M., \& Sembenelli, A. (2011). Entrepreneurship, firm entry, and the taxation of corporate income: Evidence from Europe. Journal of Public Economics, 95(9-10), 1048-1066.

\footnotetext{
${ }^{39}$ Wage data are compiled by the Swiss Federal Statistical Office for seven Swiss regions, five of which comprise several cantons (the cantons of Zurich and Ticino representing regions on their own), and for sectoral aggregates that correspond roughly to the NACE 1-digit level. These data are available for the years 2002 and 2004. We linearly extrapolate wage for the remaining years.

${ }^{40}$ We obtained these data from the consultancy firm Wüest \& Partner.
} 
de Mooij, R. A., \& Ederveen, S. (2003). Taxation and foreign direct investment: a synthesis of empirical research. International Tax and Public Finance, 10, 673-693.

de Mooij, R. A., \& Nicodème, G. (2008). Corporate tax policy, entrepreneurship and incorporation in the EU. International Tax and Public Finance, 15, 478-498.

Domar, E. D., \& Musgrave, R. A. (1944). Proportional income taxation and risk-taking. The Quarterly Journal of Economics, 58, 388-422.

Duranton, G., Gobillon, L., \& Overman, H. G. (2011). Assessing the effects of local taxation using microgeographic data. Economic Journal, 121(555), 1017-1046.

Edmiston, K., Mudd, S., \& Valev, N. (2004). Tax structures and FDI: the deterrent effects of complexity and uncertainty. Fiscal Studies, 24, 341-359.

Feld, L. P., \& Kirchgässner, G. (2003). The impact of corporate and personal income taxes on the location of firms and on employment: some panel evidence for the Swiss cantons. Journal of Public Economics, 87, 129-155.

Feldstein, M. (1969). The effects of taxation on risk taking. Journal of Political Economy, 77, 755-764.

Fritsch, M. (2008). How does new business formation affect regional development? Introduction to the special issue. Small Business Economics, 30(1), 1-14.

Gentry, W. M., \& Hubbard, G. (2000). Tax policy and entrepreneurial entry. American Economic Review, 90, 283-287.

Gentry, W. M., \& Hubbard, G. (2005). "Success taxes", entrepreneurial entry and innovation. In A. B. Jaffe, J. Lerner, \& S. Stern (Eds.), Innovation policy and the economy (Vol. 5). Cambridge: NBER/MIT Press.

Glaeser, E. L., Kallal, H. D., Scheinkman, J. A., \& Shleifer, A. (1992). Growth in cities. Journal of Political Economy, 100(6), 1126-1152.

Goolsbee, A. (2004). The impact of the corporate income tax: evidence from state organizational form data. Journal of Public Economics, 88, 2283-2299.

Gordon, R. H. (1985). Taxation of corporate capital income: tax revenues versus tax distortions. The Quarterly Journal of Economics, 100(1), 1-27.

Gordon, R. H., \& Slemrod, J. (2000). Are "real" responses to taxes simply income shifting between corporate and personal tax bases. In J. Slemrod (Ed.), Does atlas shrug? The economic consequences of taxing the rich. Cambridge: Harvard University Press.

Guimaraes, P., Figuieredo, O., \& Woodward, D. (2003). A tractable approach to the firm location decision problem. Review of Economics and Statistics, 85, 201-204.

Guimaraes, P., Figueiredo, O., \& Woodward, D. (2004). Industrial location modeling: extending the random utility framework. Journal of Regional Science, 44, 1-20.

Hagen, K. P., \& Sannarnes, J. G. (2007). Taxation of uncertain business profits, private risk markets and optimal allocation of risk. Journal of Public Economics, 91, 1507-1517.

Hall, R. E., \& Rabushka, A. (2007). The flat tax (2nd ed.). Stanford: Hoover Institution, Stanford University.

Henneberger, F., \& Ziegler, A. (2008). Eine Methode zur objektiven Bestimmung von Ober- und Untergrenzen marktkonformer Aktionä rsgehälter. Der Schweizer Treuhänder, 2008(1-2), 69-79.

Hines, J. R. (2007). Corporate taxation and international competition. In A. J. Auerbach, J. R. Hines, \& J. Slemrod (Eds.), Taxing corporate income in the 21st century. Cambridge: Cambridge University Press.

Keen, M., Kim, Y., \& Varsano, R. (2008). The flat tax(es): principles and evidence. International Tax and Public Finance, 15, 712-751.

Kesselman, J. R., \& Cheung, R. (2004). Tax incidence, progressivity, and inequality in Canada. Canadian Tax Journal, 52, 709-789.

Keuschnigg, C., \& Nielsen, S. B. (2004). Progressive taxation, moral hazard, and entrepreneurship. Journal of Public Economic Theory, 6, 471-490.

Keuschnigg, C., \& Ribi, E. (2009). Profit taxation and finance constraints (CEPR Discussion Paper\#7433). London: Centre for Economic Policy Research.

Michelacci, C. (2003). Low returns in R\&D due to the lack of entrepreneurial skills. Economic Journal, 113(484), 207-225.

Moulton, B. R. (1986). Random group effects and the precision of regression estimates. Journal of Econometrics, 32(3), 385-397.

Murphy, K. M., Shleifer, A., \& Vishny, R. W. (1991). The allocation of talent: implications for growth. The Quarterly Journal of Economics, 106(2), 503-530.

Rathelot, R., \& Sillard, P. (2008). The importance of local corporate taxes in business location decisions: evidence from French micro data. Economic Journal, 118, 499-514. 
Reynolds, P. D., Miller, B., \& Maki, W. R. (1995). Explaining regional variation in business births and deaths: US 1976-1988. Small Business Economics, 7(5), 389-407.

Schmidheiny, K., \& Brülhart, M. (2011). On the equivalence of location choice models: conditional logit, nested logit and Poisson. Journal of Urban Economics, 69(2), 214-222.

Slemrod, J. (2005). The etiology of tax complexity: evidence from U.S. state income tax systems. Public Finance Review, 33, 279-299.

Slemrod, J., \& Bakija, J. (2004). Taxing ourselves (3rd ed.). Cambridge: MIT Press.

Varian, H. R. (1980). Redistributive taxation as social insurance. Journal of Public Economics, 14(1), 49-68.

Waterson, M. (1985). On progressive taxation and risk-taking. Oxford Economic Papers, 37, 510-519. 